\title{
Mechanisms initiating deep convection over complex terrain during COPS
}

\author{
CHRistoph KOTTMEIER ${ }^{1 *}$, NORBERT KALTHOFF ${ }^{2}$, CHRISTIAN BARTHLOTT $^{1}$, UlRich \\ CORSMEIER $^{1}$, JOËL VAN BAELEN ${ }^{2}$, ANDREAS BEHRENDT ${ }^{3}$, RAINER BEHRENDT ${ }^{4}$, AlAN BLYTH ${ }^{5}$,

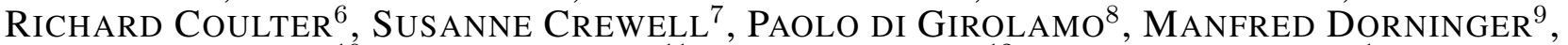

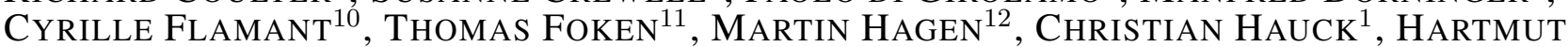 \\ Höller $^{12}$, Heike Konow ${ }^{1}$, Michael KunZ ${ }^{1}$, Holger MahlKe ${ }^{1}$, Stephen MobBS ${ }^{5}$, Evelyne \\ RICHARD $^{13}$, REINHOLD STEINACKER ${ }^{9}$, TAMMY WECKWERTH ${ }^{14}$, ANDREAS WIESER ${ }^{1}$, and VOLKER \\ WULFMEYER ${ }^{3}$
}

${ }^{1}$ Institute for Meteorology and Climate Research (IMK), Karlsruhe Institute of Technology (KIT), Karlsruhe, Germany

${ }^{2}$ Laboratoire de Météorologie Physique, Observatoire de Physique du Globe de Clermont-Ferrand, UBP/CNRS, France

${ }^{3}$ Institute of Physics and Meteorology, University of Hohenheim, Hohenheim, Germany

${ }^{4}$ Hessischer Rundfunk, Frankfurt, Germany

${ }^{5}$ National Centre for Atmospheric Science, Leeds, United Kingdom

${ }^{6}$ Argonne National Laboratory, Argonne, United States

${ }^{7}$ Institute for Geophysics and Meteorology, University of Cologne, Cologne, Germany

${ }^{8}$ Dipartimento di Ingegneria e Fisica dell' Ambiente, Università degli Studi della Basilicata, Potenza, Italy

${ }^{9}$ Department of Meteorology and Geophysics, University of Vienna, Vienna, Austria

${ }^{10}$ Université Pierre et Marie Curie, Service d'Aéronomie, Institut Pierre-Simon Laplace, Paris, France

${ }^{11}$ Department of Micrometeorology, University of Bayreuth, Bayreuth, Germany

${ }^{12}$ Institut für Physik der Atmosphäre, Deutsches Zentrum für Luft- und Raumfahrt (DLR), Oberpfaffenhofen, Germany

${ }^{13}$ Laboratoire d'Aérologie, CNRS and Université de Toulouse, France

${ }^{14}$ National Center for Atmospheric Research, Boulder, United States

(Manuscript received June 16, 2008; in revised form October 7, 2008; accepted October 7, 2008)

\begin{abstract}
Precipitating convection in a mountain region of moderate topography is investigated, with particular emphasis on its initiation in response to boundary-layer and mid- and upper-tropospheric forcing mechanisms. The data used in the study are from COPS (Convective and Orographically-induced Precipitation Study) that took place in southwestern Germany and eastern France in the summer of 2007. It is found that the initiation of precipitating convection can be roughly classified as being due to either: (i) surface heating and low-level flow convergence; (ii) surface heating and moisture supply overcoming convective inhibition during latent and/or potential instability; or (iii) mid-tropospheric dynamical processes due to mesoscale convergence lines and forced mean vertical motion. These phenomena have to be adequately represented in models in order to improve quantitative precipitation forecast. Selected COPS cases are analysed and classified into these initiation categories. Although only a subset of COPS data (mainly radiosondes, surface weather stations, radar and satellite data) are used here, it is shown that convective systems are captured in considerable detail by sensor synergy. Convergence lines were observed by Doppler radar in the location where deep convection is triggered several hours later. The results suggest that in many situations, observations of the location and timing of convergence lines will facilitate the nowcasting of convection. Further on, forecasting of the initiation of convection is significantly complicated if advection of potentially convective air masses over changing terrain features plays a major role. The passage of a frontal structure over the Vosges Rhine valley - Black Forest orography was accompanied by an intermediate suppression of convection over the wide Rhine valley. Further downstream, an intensification of convection was observed over the Black Forest due to differential surface heating, a convergence line, and the flow generated by a gust front.
\end{abstract}

${ }^{*}$ Corresponding author: Christoph Kottmeier, Institut für Meteorologie und Klimaforschung, Forschungszentrum Karlsruhe/Universität Karlsruhe, POB 3640, 76021 Karlsruhe, Germany; e-mail: christoph.kottmeier@imk.fzk.de 


\begin{abstract}
Zusammenfassung
In dieser Arbeit wird hochreichende Konvektion in einer Mittelgebirgsregion untersucht, die durch Prozesse in der Grenzschicht und in der mittleren und oberen Troposphäre ausgelöst wird. Die Daten stammen aus der COPS-Messkampagne (Convective and Orographically-induced Precipitation Study), die im Sommer 2007 in Südwestdeutschland und Ostfrankreich durchgeführt wurde. Bei der Bildung konvektiver Niederschläge können grob drei Antriebsmechanismen unterschieden werden: (i) Erwärmung der Erdoberfläche und bodennahe Massenkonvergenz, (ii) Erwärmung der Erdoberfläche mit ausreichendem Feuchteangebot in der Grenzschicht zur Überwindung der Konvektionsunterdrückung bei potentieller und/oder latenter Instabilität und (iii) Hebungsvorgänge in der mittleren Troposphäre aufgrund von Divergenz und Luftmassen- bzw. Vorticityadvektion. Ausgewählte COPS-Fälle werden anhand dieser konzeptionellen Einteilung untersucht, um diejenigen Prozesse zu identifizieren, die in Wettervorhersagemodellen für eine verbesserte quantitative Niederschlagsvorhersage adäquat repräsentiert sein müssen. Trotz der zusammenfassenden Verwendung von Daten nur ausgesuchter Messsysteme (vor allem Radiosonden, meteorologischen Bodenstationen, Radar und Satellit) wird in dieser Arbeit gezeigt, dass die konvektiven Systeme durch die Messungen sehr detailliert erfasst wurden. Durch den Nachweis von Konvergenzlinien in Radardaten bereits Stunden vor der Konvektionsauslösung wird gezeigt, dass deren Existenz und Lage entscheidende Bedeutung zukommt. Dies kann bei geeigneten Beobachtungen die Kurzfristvorhersage erleichtern. Im Falle der Advektion labiler Luftmassen über komplexem Gelände ist die Vorhersage der Konvektionsauslösung deutlich erschwert. Die Passage einer frontähnlichen Struktur über Vogesen, Rheingraben und Schwarzwald ging mit Konvektionsunterdrückung über dem vergleichsweise breiten Rheingraben einher. Weiter stromab über dem Schwarzwald wurde Konvektionsverstärkung durch differentielle Bodenerwärmung, eine Konvergenzlinie und die durch eine Böenfront verursachte Strömung beobachtet.
\end{abstract}

\section{Introduction}

Quantitative Precipitation Forecasting (QPF) on regional scales is still inadequate for many applications such as in hydrology and flood forecasting. For this purpose, it is essential to simulate precipitation accurately down to the size of small catchment areas. Within the frame of the Convective and Orographically-induced Precipitation Study (COPS; WULFMEYER et al., 2008), the focus is on the formation and organisation of convective precipitation systems in a low-mountain region. Several problems in connection with QPF have been identified for mountain regions (e.g. Schwitalla et al., 2008), which include the overestimation and underestimation of precipitation on the windward and lee side of the mountains, respectively, and a phase error in the diurnal cycle of precipitation leading to the onset of convective precipitation in model forecasts several hours too early. The latter has been an outstanding issue in numerical weather prediction (NWP) research for a long time (e.g. Chaboureau et al., 2004).

Several field campaigns have been performed in recent years addressing convection initiation (CI) and evolution in different landscapes. The International $\mathrm{H}_{2} \mathrm{O}$ Project (IHOP_2002) performed in the southern Great Plains (US) focussed on surface-forced initiation of deep convection and its prediction over flat and gently rolling terrain where large convective instability and strong capping inversions are frequent (WECKWERTH et al., 2004). Special emphasis was placed on mesoscale wind and humidity discontinuities in the planetary boundary layer (PBL), e.g. frontal zones and drylines, which often prove to be responsible for triggering deep convection (WILSON and ROBERTS, 2006; WECKWERTH and PARSONS, 2006).

During the VERTIKATOR project (Vertikaler Austausch und Orographie; vertical exchange and orography) in the low mountain range of the Black Forest in

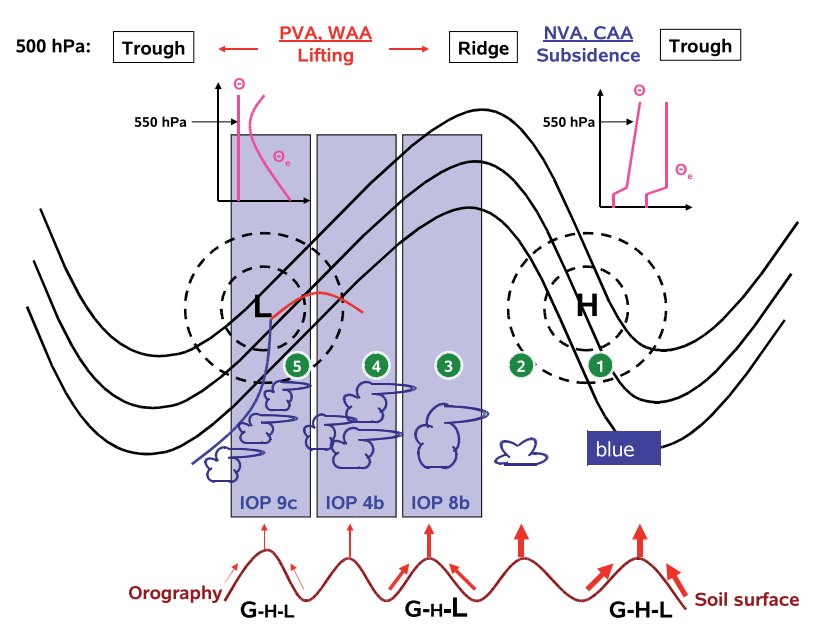

Figure 1: Sketch of prevailing synoptic settings and orographic effects for convection initiation processes. The blue columns represent the conditions met during IOP 9c, IOP $4 \mathrm{~b}$, and IOP $8 \mathrm{~b}$. Signatures: $500 \mathrm{hPa}$ flow (solid black), surface pressure systems (Low, High, dashed), warm fronts (red), cold front (blue), positive and negative vorticity advection (PVA, NVA), warm air and cold air advection (WAA, CAA), typical vertical profiles of potential temperature $(\Theta)$ and equivalent potential temperature $\left(\Theta_{e}\right)$ downstream the trough and ridge, surface orography (brown solid), components of the surface energy balance: radiation budget $(G)$, sensible heat flux $(H)$, latent heat flux (L), cloud coverage ranging from blue sky (1) over single convective cells (2 and 3), organised deep convection (4) to overcast sky with embedded convection (5). For detailed explanation see text.

southwestern Germany in 2002, the influence of the spatial variability of the energy exchange at the Earth's surface in combination with orographically-induced wind systems on shallow and deep convection and its model representation was investigated. It was shown that the onset and intensity of convection depend on the largescale humidity convergence and turbulent fluxes of la- 
Table 1: Classification of individual IOPs.

\begin{tabular}{|l|c|c|c|c|c|}
\hline Type & $\begin{array}{c}\text { Type I: Locally } \\
\text { initiated } \\
\text { convection }\end{array}$ & $\begin{array}{c}\text { Type II: Convection } \\
\text { favoured by large- } \\
\text { scale lifting }\end{array}$ & $\begin{array}{c}\text { Type III: } \\
\text { Convection near } \\
\text { convergence lines } \\
\text { or frontal zones }\end{array}$ & $\begin{array}{c}\text { Combination of } \\
\text { Type I and II }\end{array}$ & $\begin{array}{c}\text { Post-frontal cold } \\
\text { air convection }\end{array}$ \\
\hline $\begin{array}{l}\text { Numbers of } \\
\text { IOP days }\end{array}$ & 12 & 5 & 15 & 2 & 1 \\
\hline
\end{tabular}

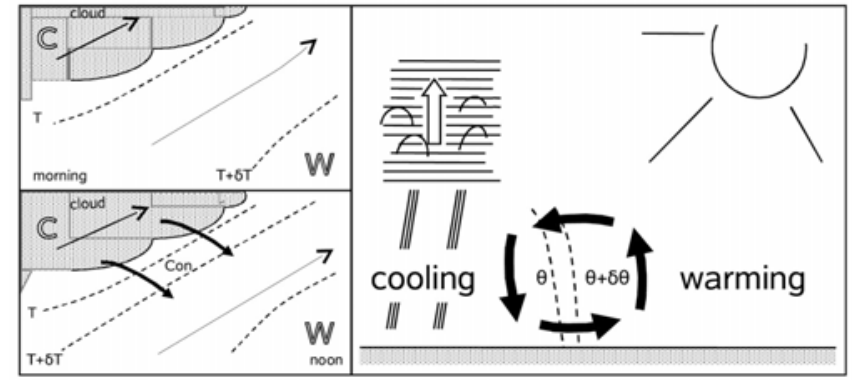

Figure 2: Conceptual model of the development of a thermally direct circulation pattern on the fringes of cloud and precipitation zones. Within a few hours, resulting prefrontal convergence zones may rapidly lead to squall lines combined with heavy precipitation (Kurz, 1984).

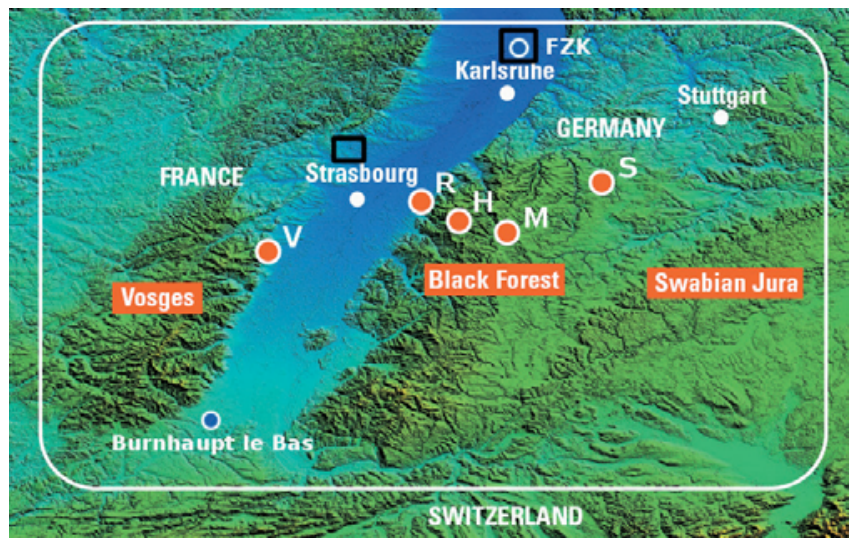

Figure 3: The COPS domain in southwestern Germany and eastern France. Supersites are marked with orange filled circles, additional radiosonde stations with blue filled circles. The location of POLDIRAD to the north of Strasbourg and FZK precipitation radar northward of Karlsruhe are marked with black squares.

tent heat at the surface. Both processes were more realistically represented in the COSMO model (Consortium for Small-scale Modeling, SCHÄTTLER et al., 2008) from the German Weather Service (DWD) with $2.8 \mathrm{~km}$ grid resolution compared to $7 \mathrm{~km}$. The higher model resolution also gave a better representation of the flow pattern in mountainous areas (BARTHLOTT et al., 2006).

The Convective Storms Initiation Project (CSIP 2004 and 2005) was performed in southern UK in a region characterised by gently rolling terrain, a nearby coastline and remote major mountain ranges. In this area the convective instability and capping inversions are often quite weak on convective days. During CSIP in almost

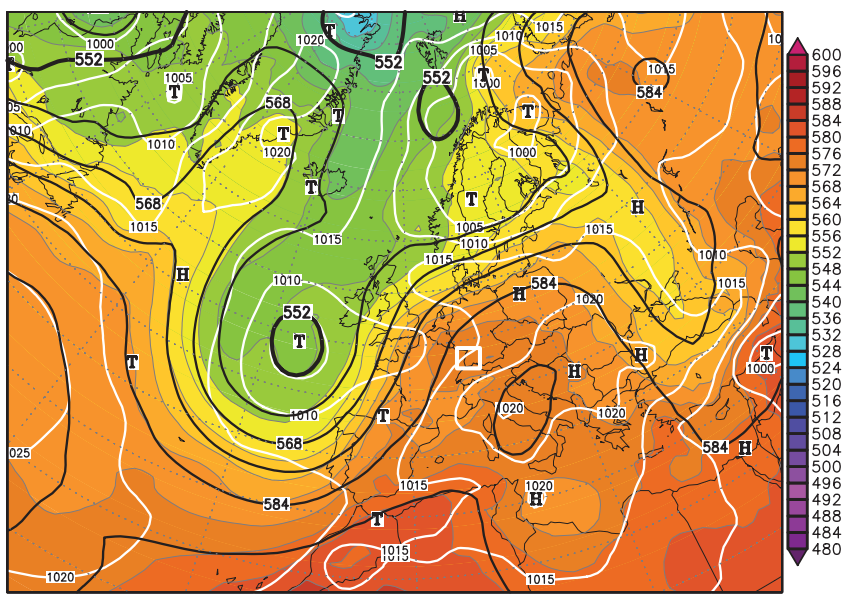

Figure 4: GFS-analysis of IOP 8b, July 15, 2007, 1200 UTC: surface pressure in $\mathrm{hPa}$ (white isolines), $500 \mathrm{hPa}$ in gpdm (black isolines), and relative topography in gpdm (colour code). The COPS area (white rectangle) is located in between a western European trough and an eastern European ridge (all GFS charts courtesy of www.wetter3.de).

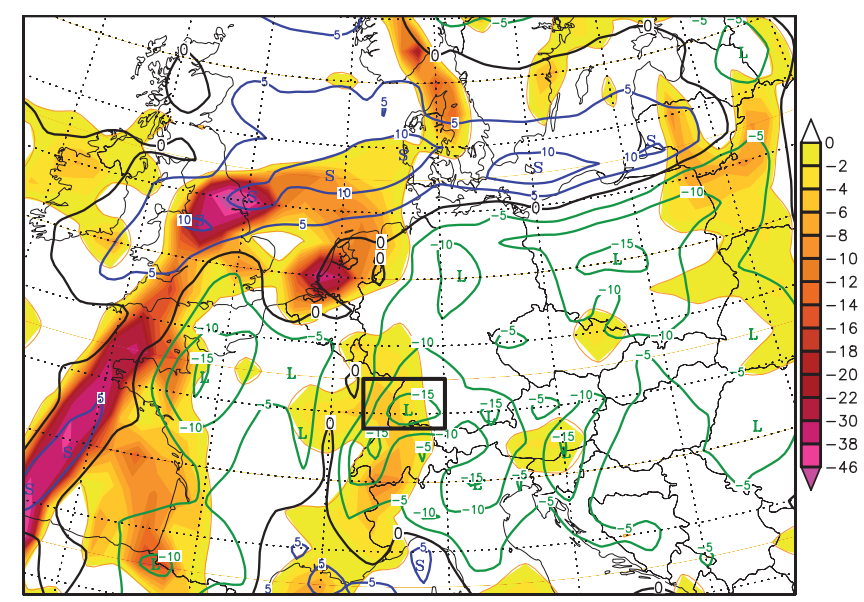

Figure 5: GFS-analysis of IOP 8b, July 15, 2007, 1200 UTC: KOindex in $\mathrm{K}$ (isolines) and $500 \mathrm{hPa}$ vertical motion in $\mathrm{hPa} \mathrm{h}^{-1}$ (colour code). The COPS area is indicated by the black rectangle.

every case convection was initiated in the atmospheric boundary layer. So-called "lids", layers of warm, dry air that separate humid lower tropospheric air from potentially colder air in the middle and upper troposphere, were shown to influence CI critically (BROWNING et al., 2007).

During a particular case of the PRINCE field campaign (Prediction, Identification and Tracking of Con- 

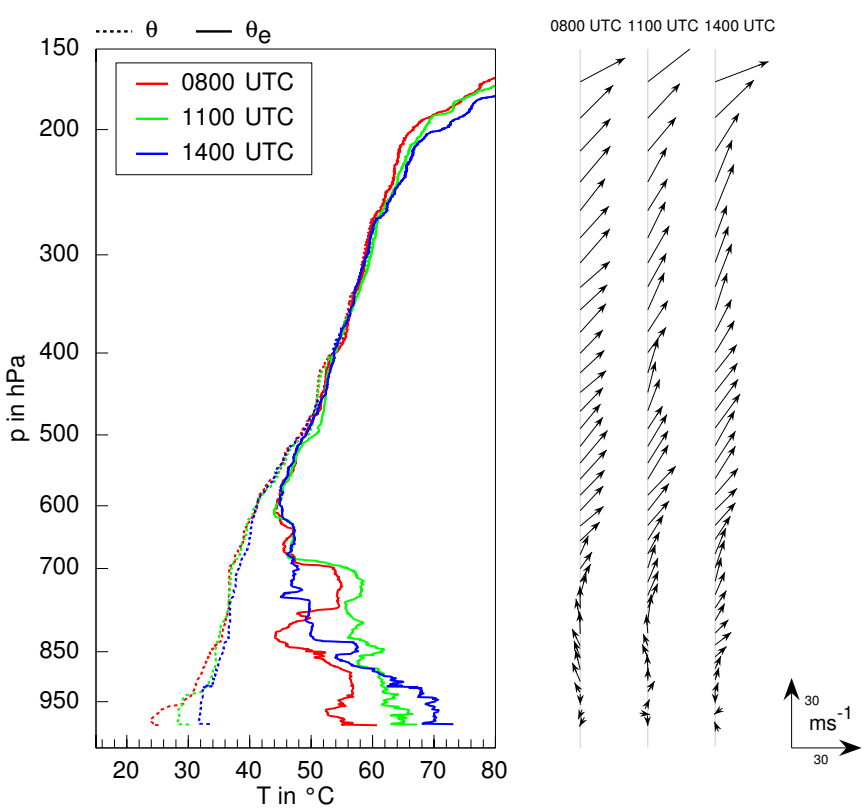

Figure 6: IOP 8b, July 15, 2007: Vertical profiles of potential temperature, equivalent potential temperature and horizontal wind speed from 0800, 1100 and 1400 UTC at supersite Achern, approx. $30 \mathrm{~km}$ northwest of the deep convective cell that developed near Freudenstadt.

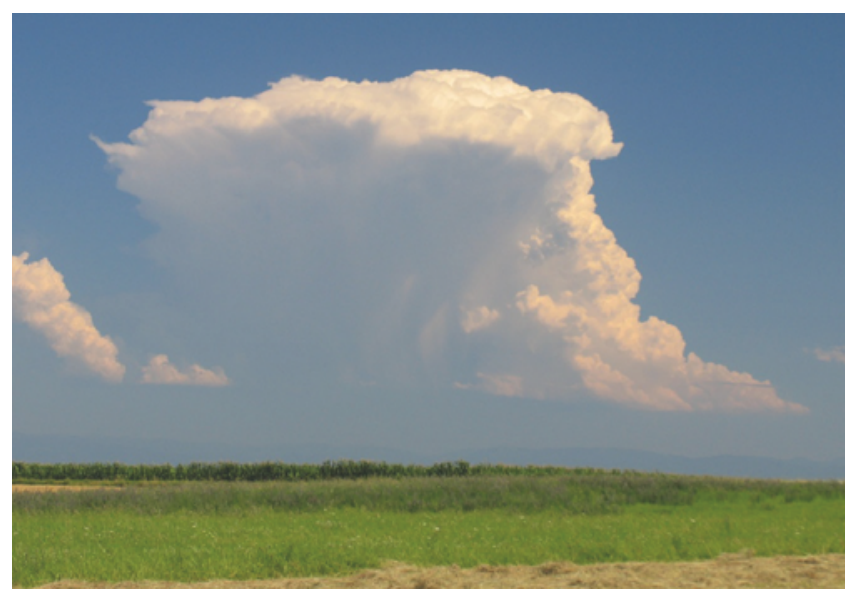

Figure 7: IOP 8b, July 15, 2007, 1445 UTC: The Cb-cloud over the northern Black Forest at the summit of its development, seen from the location of DLR-Poldirad radar in the Rhine valley (Fig. 3).

vective Cells) in the northern Black Forest in southwest Germany in July 2006 (GROENEMEIJER et al., accepted), Doppler lidar data from the highest mountain in that area (Hornisgrinde, $1163 \mathrm{~m}$ ) indicated local circulation systems over the western slopes. Results from one case from PRINCE showed that the storm studied changed its environment considerably. A warm and dry downdraught of $10 \mathrm{~km}$ in diameter occurred under the decaying parts of the storm. It caused a reduction of lowlevel moisture and warming in the lower troposphere that both acted to reduce CAPE and to increase CIN. This is an important factor preventing subsequent convective development in the near vicinity of the original storm system.

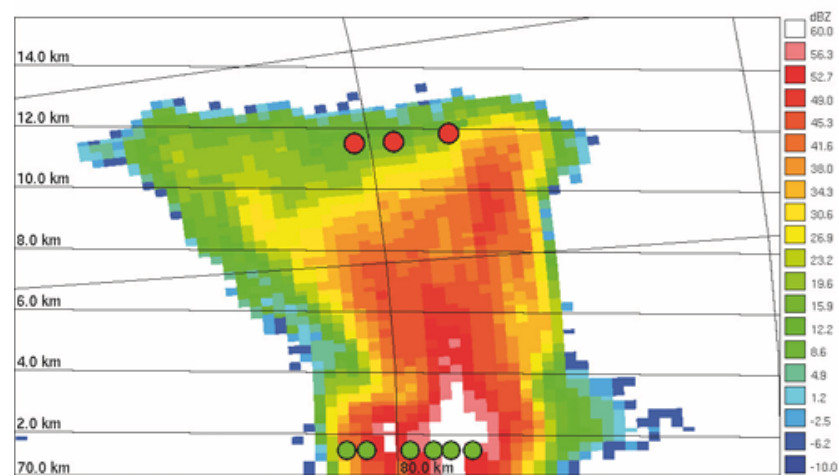

Figure 8: IOP 8b, July 15, 2007, 1445 UTC: The reflectivity of the Cb-cloud given in dBZ (colour code) seen with DLR-Poldirad radar. Few inter-cloud strokes are detected in the upper part of the $\mathrm{Cb}$ (red dots) and cloud-to-ground strokes are found below the $\mathrm{Cb}$ (green dots).

During COPS the pre-convective conditions and deep convective systems were observed in all their stages of development with ground-based and airborne instruments. Based on surface, in-situ, and remote sensing data, 4D data sets of key meteorological variables were acquired in order to understand convection initiation processes and hence improve mesoscale model forecasts of convective precipitation by e.g. advanced mesoscale data assimilation projects (ZUS et al., 2008).

\section{Convection initiation issues addressed in this study}

For planning the operation of the adaptive instrumentation within COPS (WULFMEYER et al., 2006), the conceptual idea assumed that deep convection tends to occur in response to three distinct trigger mechanisms. Firstly, CI takes place at many locations in the whole domain, when surface heating and moisture supply overcome convective inhibition during potentially unstable stratification. Secondly, locally confined convection may be initiated by low-level flow convergence near hot spots at the surface and over mountain crests. The third trigger mechanism is associated with mid-tropospheric lifting due to divergence, mesocale vorticity advection, and differential temperature advection. We summarise the relative importance of the trigger mechanisms depending on the prevailing synoptic conditions for CI schematically in Fig. 1. The $500 \mathrm{hPa}$ flow is of major importance for the large-scale distribution of cloudiness, stratification and mean vertical motion in the region of interest. The progression of the $500 \mathrm{hPa}$ troughs and ridges causes the day-to-day variability of this influence. Lifting is generated by positive vorticity advection and warm air advection, whereas subsidence occurs with negative vorticity advection and cold air advection related to the position of the troughs and ridges. The surface pressure systems and mesoscale features such as warm and cold fronts as 

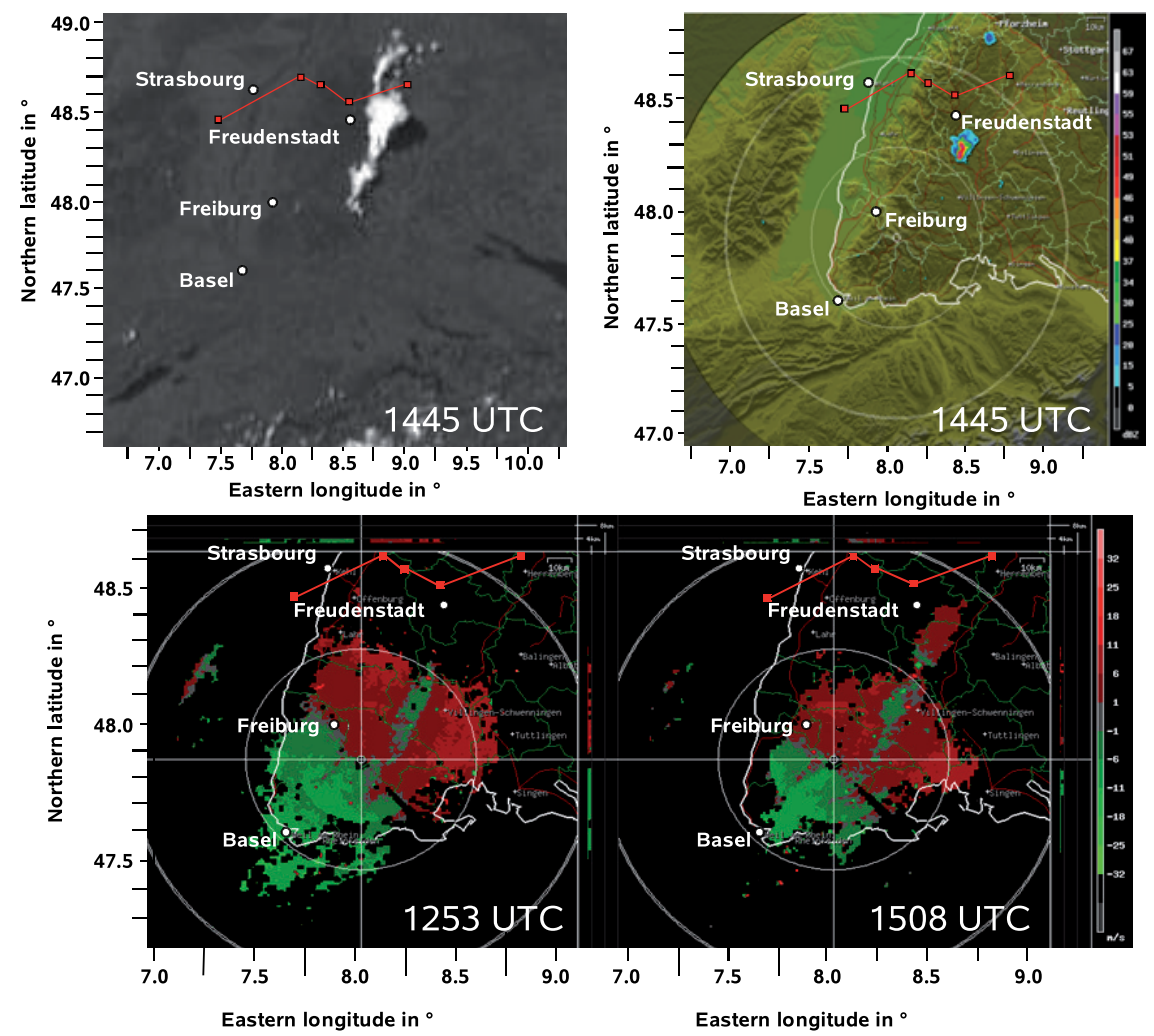

Figure 9: IOP 8b, July 15, 2007: MSG satellite image showing single convective cells over the COPS area at 1445 UTC (upper left; courtesy of EUMETSAT) and synchronous radar reflectivity indicating precipitation (upper right) and line of sight Doppler velocity at 1253 UTC and 1508 UTC measured and calculated from DWD radar Feldberg (lower row). Green indicates a wind component to the radar and red gives wind away from the radar. The red rectangles show the location of the supersites.

well as short-wave troughs (not shown) may be decisive factors for the development and intensity of deep convection. The stratification of the air mass, represented by typical vertical profiles of potential temperature $(\Theta)$ and equivalent potential temperature $\left(\Theta_{e}\right)$ downstream of the trough and ridge are important for the potential of the atmosphere to allow the development of deep convection. Finally, mesoscale features caused by surface inhomogeneities, determine where and when convection inhibition factors like PBL-capping inversions and lids will be resolved.

Convection initiation and convective precipitation during COPS was classified according to this scheme. Three IOPs were selected to represent the prototypic situations. These are IOP $8 \mathrm{~b}$ on July 15,2007 , with locally initiated convection, IOP 4 b on June 20 , 2007, with widespread convection triggered by large-scale lifting of potentially unstable air masses, and IOP 9c on July 20 , 2007 with convection near convergence lines and frontal zones. Data of the dense ground-based, airborne and space-based network of in-situ and remote sensing instruments operated during COPS as well as operational analyses of the Global Forecast System (GFS) at a resolution of $35 \mathrm{~km}$ (T382) are used for analyses.

\subsection{Surface and boundary layer forcing mechanisms}

The triggering or modification of convection in the boundary layer is often bound to spatial inhomogeneities of land use and/or soil water content. Under weak synoptic forcing these quantities control the energy balance of the Earth's surface, resulting in inhomogeneities in the atmospheric temperature and moisture fields and hence determine if and where the trigger (or convective temperature) is reached. Especially the low-level and boundary-layer moisture fields (WECKWERTH, 2000; LASCAUX et al., 2004) or convergence lines (WILSON and SCHREIBER, 1986; WILSON et al., 1998) often have a significant impact on convection. Mountainous terrain may induce thermally driven wind systems like slope, mountain, and plateau winds that were identified to be important for CI via mesoscale convergence regions. The Black Forest mountains are well known for slope and valley winds (KOSSMANN and FIEDLER, 2000; KALTHOFF et al., 2000) resulting in mountain venting over the mountain crests (FIEDLER et al., 2000) and therefore are favourable for earlier and more intense convection (BARTHLOTT et al., 2006; MEISSNER et al., 2007) than the surrounding lowlands. 


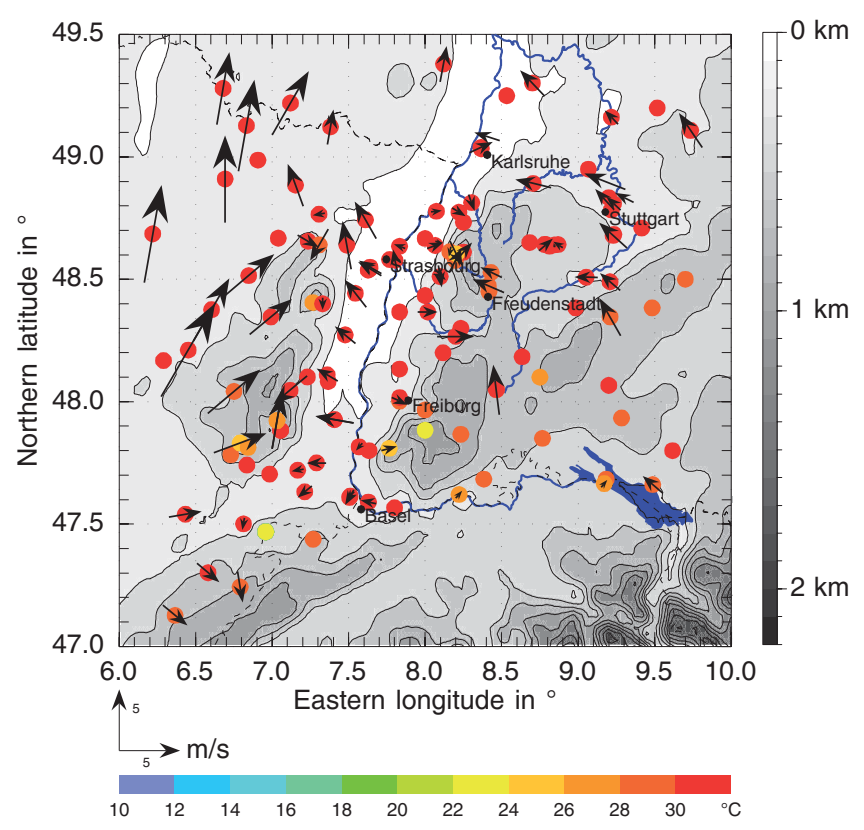

Figure 10: Near-surface wind (arrows) and temperature (colour code) on July 15, 2007, 1300 UTC.

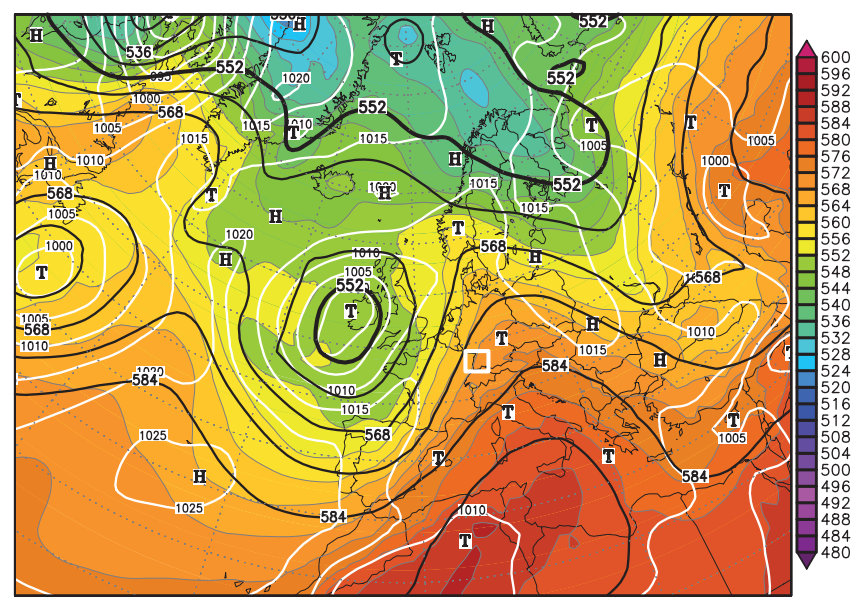

Figure 11: As Fig. 4 but GFS-analysis of IOP 4b, June 20, 2007, 1800 UTC. The COPS area (white rectangle) is located downstream of a western European long wave trough.

PBL-capping inversions influence convection in two ways. They may act as a barrier preventing convective plumes and clouds to break through and, thus, inhibit the development of deep convection. On the other hand lids which exist over several days may lead to the accumulation of moisture in the PBL and result in an increase of convective instability and subsequent breakout of deep convection. Several processes have been identified, such as subsidence or horizontal advection in or above the PBL, which contribute to the evolution of PBL-capping inversions (KossmANN et al., 1998; 1999). Great spatial variations of the inversion height and strength can be observed in the Black Forest area (KALTHOFF et al., 1998).

\subsection{Forcing and suppressing mechanisms in the middle and upper troposphere}

Among the middle and upper tropospheric forcing mechanisms, embedded convection within convergence lines and frontal zones is of primary importance. Their poor representation in forecast models is usually held responsible for the corresponding low precipitation forecast skill especially in summer. Ahead of a trough, direct thermal circulation systems develop, sharpening convergence lines and frontal zones. Enhanced instability explains the formation of embedded convection, forming thunderstorms and squall lines with increased risk of severe weather.

The scale of this process is between $20 \mathrm{~km}$ and $100 \mathrm{~km}$. The numerical simulation of such a development by operational models is challenging because of the limited scale of the process, its fast development within only a few hours, and the coarse observation network. Therefore the QPF is often unsatisfactory in these cases. Fig. 2 shows the conceptual model of the process according to KURZ (1984). While under the cloud layer of a cold front the daily temperature amplitude is quite weak, there is a prefrontal zone with clear sky and high insolation resulting in high near-surface temperatures. This causes the horizontal temperature gradient to increase significantly during the day. A thermal circulation develops, while the wind, humidity, and temperature fields are modified by the state of the surface. This explains the triggering of convection at the convergence line which may lead to squall lines. Precipitation and gusts may be heavy and in most cases unforeseen, because even if the prediction of the convergence or a front is correct, the smaller scale inhomogeneities in the fields of the relevant meteorological variables which are responsible for the convection generation are neither recorded by the operational network nor predicted by the models. On a larger scale of up to several hundreds of kilometres, at the transition zone between a ridge and a trough, lifting can be caused by upper tropospheric divergence. If the lifted air mass is potentially unstable, widespread convection can be triggered rapidly. In this case a large number of precipitation events with a high amount of rainfall of limited extent is typical. COSMO simulations show that in such cases the rainfall starts too early in the day and area-averaged intensities are too high.

\section{The COPS field campaign}

COPS was performed from June 1 to August 31, 2007 in southwestern Germany and eastern France (Fig. 3). In summertime, this region is often characterised by severe thunderstorm activity with low QPF skill. In order to study the whole chain of events leading to precipitation, five supersites with a large number of different instruments were deployed in the COPS region. 

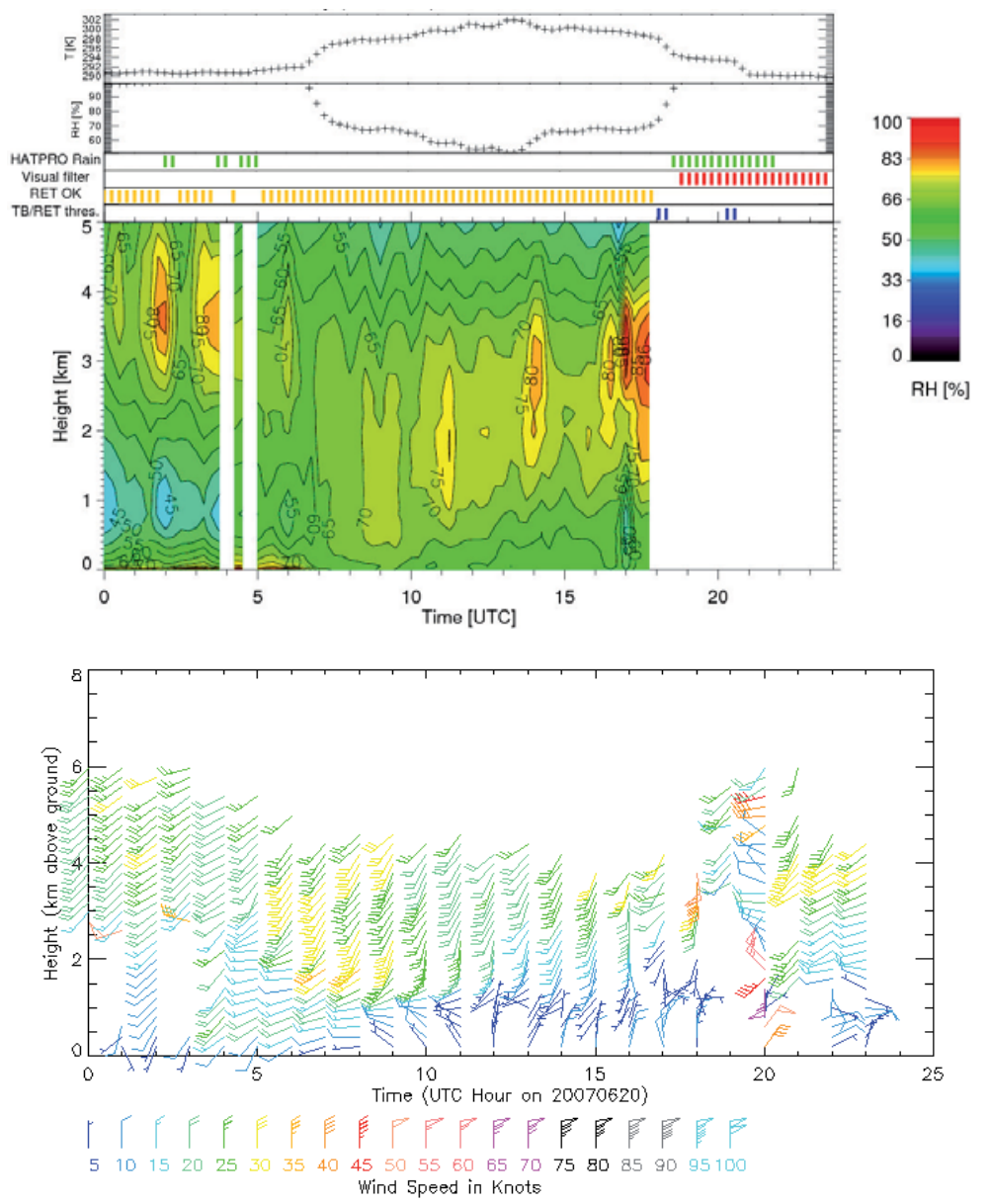

Figure 12: Diurnal cycle of near-surface temperature and humidity as well as profiles of relative humidity (top) and vertical profiles of horizontal wind vectors (bottom) at supersite M (Murg valley, Fig. 3) on June 20, 2007. Up-valley winds are represented by northerly wind directions from around 0900 to 2000 UTC in the lowest $\mathrm{km}$.

They were operated along a transect through the COPS region in order to optimise the observation of convergence above ridges and to study windward/lee effects. The supersites are called supersite $\mathrm{V}$ (Vosges low mountain region), $\mathrm{R}$ (Rhine valley), $\mathrm{H}$ (Hornisgrinde mountain site), M (Murg valley), and S (Dornstetten close to Stuttgart). They were equipped with state-of-the-art remote sensing instruments (e.g. wind and water vapour lidar, cloud radar, radiometers, microwave radar) resulting in a beneficial sensor synergy. In addition, standard meteorological measurements were made and radiosondes were launched at up to 2-hourly intervals. Two additional radiosonde stations in Burnhaupt le Bas and at Forschungszentrum Karlsruhe (FZK) provided additional information about the vertical structure of the atmosphere at the northern and southern borders of the COPS region. The IMK C-band radar at FZK and the C-band Poldirad of DLR Oberpfaffenhofen located close to Strasbourg extended the existing German, French, and Swiss radar network. Research networks measuring soil moisture (KRAUSS et al., submitted), energy balance, near surface turbulence, and standard meteorological parameters were set up and sta- tions were added to the GPS (Global Positioning System) network. A sodar and wind profiler network was operated to study the boundary layer wind field. Mobile teams in the field included five IMK teams with radiosonde launching equipment and two US Doppleron-Wheels (DOWs). Rapid Scanning (RS) service from Meteosat-8 (Meteosat Second Generation, MSG) provided five-minute scans which were used to observe the evolution of convective clouds and to detect convection initiation sites (AOSHIMA et al., 2008). Altogether 9 aircraft and an instrumented airship Zeppelin NT were operated, either dedicated to boundary-layer observations (e.g. DO 128, Dimona motorglider) or mapping the large-scale conditions (e.g. 2 Falcons F20, BAe146). The operations centre (www.cops2007.de) was located at Baden-Airpark in the Rhine valley. The COPS field phase was successfully performed with intense links to other projects, e.g. the "General Observations Period" (GOP; CREWELl et al., 2008) or the Forecast Demonstration Project (FDP) "Demonstration of Probabilistic Hydrological and Atmospheric Simulation of Flood Events in the Alpine Region" (D-PHASE; ROTACH et al., submitted). In addition, COPS was supported by 
Table 2: Convective indices during IOP $8 b$ (July 15, 2007) at COPS sites Burnhaupt, Karlsruhe and supersite R (Achern, Fig. 3): CAPE, CIN, trigger temperature (T_trig), air temperature at $2 \mathrm{~m}$ (T_2m), KO-Index (KO) and Lifted Index (LI). CAPE, CIN, and LI are calculated using the mean temperature and moisture values through the lower $50 \mathrm{hPa}$.

\begin{tabular}{|c|c|c|c|c|c|c|}
\hline \multicolumn{7}{|c|}{ Burnhaupt } \\
\hline UTC & CAPE $\left(\mathrm{J} \mathrm{kg}^{-1}\right)$ & $\mathrm{CIN}\left(\mathrm{J} \mathrm{kg}^{-1}\right)$ & T_trig $\left({ }^{\circ} \mathrm{C}\right)$ & $\mathrm{T} \_2 \mathrm{~m}\left({ }^{\circ} \mathrm{C}\right)$ & $\mathrm{KO}(\mathrm{K})$ & LI (K) \\
\hline 0500 & not def. & not def. & 35.8 & 15.7 & -1.3 & 2.9 \\
\hline 0800 & not def. & not def. & 34.8 & 25.1 & -7.0 & 0.3 \\
\hline 1100 & 483 & 253 & 34.9 & 29.9 & -12.9 & -2.6 \\
\hline 1400 & 301 & 180 & 37.0 & 33.1 & -14.1 & -1.5 \\
\hline 1700 & 45 & 299 & 35.4 & 29.7 & -13.8 & 0.8 \\
\hline 2000 & 486 & 167 & 35.5 & 20.3 & -14.6 & -1.5 \\
\hline \multicolumn{7}{|c|}{ Karlsruhe } \\
\hline 0500 & 7 & 523 & 35.5 & 16.9 & -3.7 & 1.9 \\
\hline 0800 & not def. & not def. & 36.1 & 25.5 & -4.9 & 2.1 \\
\hline 1100 & 408 & 147 & 37.7 & 32.8 & -6.1 & -0.8 \\
\hline 1700 & 1201 & 187 & 37.7 & 32.4 & -11.5 & -3.7 \\
\hline \multicolumn{7}{|c|}{ Achern } \\
\hline 0527 & not def. & not def. & 35.6 & 21.1 & -1.6 & 5.2 \\
\hline 0757 & not def. & not def. & 36.7 & 25.2 & -2.1 & 3.6 \\
\hline 1059 & 90 & 327 & 36.6 & 30.1 & -9.9 & 0.1 \\
\hline 1353 & 1123 & 183 & 36.6 & 33.4 & -14.9 & -3.0 \\
\hline
\end{tabular}

an initiative of German Helmholtz Centres within the framework of the "Transport and Chemical Conversion in Convective Systems" project TRACKS. More details are given in the COPS field report available at www.unihohenheim.de/cops/further_reading/further_reading.htm/.

\section{Case studies}

During the COPS field campaign, 18 intensive observation periods (IOPs) were conducted providing a comprehensive data set covering many different atmospheric conditions. Due to the fact that some IOPs lasted for two or more consecutive days, the number of IOP days is 35 . We classify the individual days regarding the type of observed convection: (i) locally initiated convection, (ii) widespread convection triggered by large-scale lifting of potentially unstable air masses, and (iii) embedded convection near convergence lines or frontal zones (Tab. 1). However, a mixture or combination of these categories was necessary to describe those days which could not be categorised into one single category only. A complete overview of the weather conditions, the operations plans including aircraft missions, and the instruments' facility status is available at www.cops2007.de.

Within the conceptual framework (Section 2) three COPS-cases are chosen to demonstrate typical phenomena responsible for CI. They are discussed to elucidate, (i) how small-scale inhomogeneities of humidity, temperature, and wind in the boundary layer over complex terrain affect CI, (ii) how the diurnal cycle of boundarylayer development controls the timing of CI, and (iii) how effective the relative contribution of boundary-layer processes is compared to middle and upper-tropospheric forcing mechanisms.

\subsection{Locally initiated convection (IOP 8b, July 15, 2007)}

On this day, the COPS area is located in the transition zone between an eastern European ridge, stretching from the Mediterranean Sea to Poland and a high amplitude eastern Atlantic trough (Fig. 4). Near the surface a shallow low develops in southwestern France resulting in a weak pressure fall in the COPS domain, while at the $500 \mathrm{hPa}$ level, the ridge still dominates. This leads to little advection of positive vorticity in the upper troposphere and warm air in the lower troposphere throughout the whole day. As a consequence, the large-scale forcing is of minor importance with weak lifting of up to $-6 \mathrm{hPa} \mathrm{h}^{-1}$ concentrated in the western part of the COPS area over the Vosges (Fig. 5). Low cloud conditions allow high insolation resulting in a very high PBL temperature. In combination with the orography this favours the development of local circulation systems over the mountain range.

The warm but very dry air masses do not allow for early or widespread convection to develop. The maximum $2 \mathrm{~m}$ temperature of $33{ }^{\circ} \mathrm{C}$ (Tab. 2) was less than the 
Table 3: Convective indices during IOP $4 \mathrm{~b}$ (June 20, 2007) at COPS sites Burnhaupt, Karlsruhe and supersite R (Achern, Fig. 3): Explanation of abbreviations: see Tab. 2.

\begin{tabular}{|c|c|c|c|c|c|c|}
\hline \multicolumn{7}{|c|}{ Burnhaupt } \\
\hline UTC & CAPE $\left(\mathrm{J} \mathrm{kg}^{-1}\right)$ & $\mathrm{CIN}\left(\mathrm{J} \mathrm{kg}^{-1}\right)$ & $\mathrm{T}$ trig $\left({ }^{\circ} \mathrm{C}\right)$ & $\mathrm{T} \_2 \mathrm{~m}\left({ }^{\circ} \mathrm{C}\right)$ & $\mathrm{KO}(\mathrm{K})$ & $\mathrm{LI}(\mathrm{K})$ \\
\hline 0500 & 0 & not def. & 29.9 & 19.3 & -4.8 & 0.6 \\
\hline 0800 & 69 & 124 & 25.2 & 23.7 & -5.8 & 1.2 \\
\hline 1100 & 568 & 37 & 26.9 & 27.2 & -9.2 & -1.2 \\
\hline 1400 & 1299 & 45 & 29.2 & 29.5 & -12.6 & -3.7 \\
\hline 1700 & 891 & not def. & 27.6 & 25.5 & -8.9 & -3.4 \\
\hline 2000 & 6 & not def. & 27.6 & 21.0 & -7.0 & -0.0 \\
\hline 2330 & 124 & not def. & 28.9 & 19.0 & -6.5 & -1.0 \\
\hline \multicolumn{7}{|c|}{ Karlsruhe } \\
\hline 0500 & 33 & 419 & 32.2 & 20.2 & -3.9 & 2.0 \\
\hline 0800 & 97 & 180 & 29.5 & 24.9 & -6.6 & 0.5 \\
\hline 1100 & 513 & 76 & 27.3 & 27.4 & -6.6 & -1.1 \\
\hline 1400 & 452 & 42 & 27.9 & 28.0 & -7.1 & -1.4 \\
\hline 1700 & 436 & 52 & 27.6 & 27.3 & -8.1 & -1.3 \\
\hline 2000 & 0 & not def. & 27.1 & 22.3 & -9.7 & -2.6 \\
\hline \multicolumn{7}{|c|}{ Achern } \\
\hline 0514 & not def. & not def. & 32.7 & 24.1 & -3.5 & 3.6 \\
\hline 0807 & 30 & 85 & 26.9 & 24.5 & -6.5 & 1.0 \\
\hline 1107 & 69 & 116 & 32.5 & 27.3 & -5.2 & -0.0 \\
\hline 1407 & 71 & 136 & 31.3 & 26.6 & -4.9 & 0.0 \\
\hline 1744 & 94 & 118 & 31.3 & 25.0 & -5.4 & -1.6 \\
\hline 1956 & 282 & not def. & 26.5 & 23.9 & -9.6 & -2.3 \\
\hline 2257 & 0 & 308 & 30.3 & 20.7 & -9.0 & 2.8 \\
\hline
\end{tabular}

necessary convective temperature of $34^{\circ} \mathrm{C}$ in the northern Rhine valley near Karlsruhe and $38^{\circ} \mathrm{C}$ at Burnhaupt in the south. Thus, the moderate CAPE (calculated using the mean temperature and moisture values through the lower $50 \mathrm{hPa}$ ) in the northern (Karlsruhe: $1201 \mathrm{~J} \mathrm{~kg}^{-1}$ at 1700 UTC) and western-central COPS region (Achern: $1123 \mathrm{~J} \mathrm{~kg}^{-1}$ at 1353 UTC) is not released by buoyancy. The convective index, $\mathrm{KO}$, defined as

$$
K O=\frac{1}{2}\left(\Theta_{e, 500}+\Theta_{e, 700}\right)-\frac{1}{2}\left(\Theta_{e, 850}+\Theta_{e, 1000}\right)
$$

with equivalent potential temperature at the levels 500 , 700,850 and $1000 \mathrm{hPa}$, shows a significant horizontal gradient ranging from high instability $(\mathrm{KO}<-15 \mathrm{~K})$ in the southeastern COPS area to moderate instability (KO $\sim-5 \mathrm{~K})$ in the northwestern region in the GFS analysis (Fig. 5). This spatial distribution is in general accordance with the KO index calculated from COPS vertical soundings (Tab. 2). However, the measured absolute values are generally lower than the modelled ones. This difference is partly caused by using different surface values: Instead of a $1000 \mathrm{hPa}$ value (Eq. 1), a mean value over a $15 \mathrm{hPa}$ layer is used for the radiosonde data. The Lifted Index (LI) corresponds to the KO index, but differs more between sites and in time. Fig. 6 displays three radiosoundings at the supersite Achern in the Rhine valley between 0800 UTC and 1400 UTC near the location where the convective cell develops. Besides little warming in the PBL in the diurnal cycle, the whole troposphere is very dry, with shallow intermediate moister layers between $870 \mathrm{hPa}$ and $700 \mathrm{hPa}$. Above the mountain crests (1500 m to $2000 \mathrm{~m} \mathrm{MSL}$ ) the wind direction turns from southeast to southwest between 1100 UTC and 1400 UTC when a cumulonimbus cloud $(\mathrm{Cb})$ develops southeast of Achern over the Black Forest.

On this day, convection initiation in the COPS area is neither favoured by large-scale lifting, nor by surface triggered buoyancy. Even when convection is released locally, due to the dry troposphere, no widespread deep convection is expected. Nevertheless, a line of convective clouds, including one cumulonimbus, develops, causing rainfall and lightning over the Black Forest between 1300 UTC and 1600 UTC.

Although, e.g. in the Kinzig valley, a period a free convection is obvious from ground based measurements from 0810 UTC to 0850 UTC, i.e. the buoyancy term is larger than the shear term (EIGENMANN et al., 2008), the whole COPS area is free of clouds before noon (not shown). At 1130 UTC single cumulus humilis develop simultaneously over the Vosges and the Black Forest. 


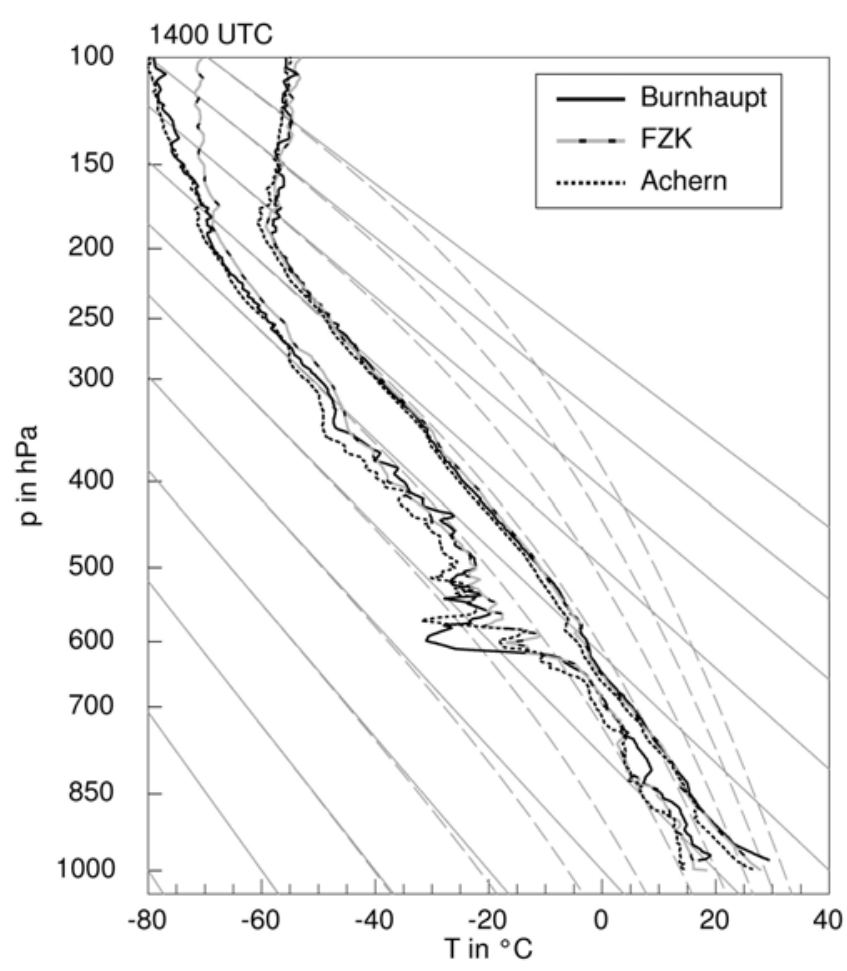

Figure 13: IOP 4b, June 20, 2007, 1400 UTC: Temperature and humidity vertical profiles from the south (Burnhaupt) over the COPS supersite R (Achern) to the north of the COPS area (FZK).

At 1300 UTC the clouds over the Vosges have disappeared but the cumuli over the Black Forest start growing, forming two north-south orientated lines of cumulus mediocris and cumulus congestus over the northern and southern Black Forest. At 1420 UTC both cumulus cloud lines unite and at the centre of the line, southeast of Freudenstadt, one $\mathrm{Cb}$ develops rapidly within 25 minutes up to a height of $12 \mathrm{~km}$ (Fig. 7) as seen from DLR radar (Fig. 8). The reflectivity in the centre of the $\mathrm{Cb}$ is high $(60 \mathrm{dBZ})$, indicating local heavy precipitation and maybe some hail (not observed at ground stations). Lightning is detected within and below the cloud by the DLR-LINET system. The peak of the cloud development is at 1445 UTC (Fig. 9). At this time the line of cumulus congestus clouds north and south of the $\mathrm{Cb}$ starts to decay, while the $\mathrm{Cb}$ in the centre of the cloud line produces rain south of Freudenstadt and creates its cirrus anvil moving to the north. An hour later, at 1545 UTC, the $\mathrm{Cb}$ has completely dissolved. Parts of the anvil's cirrus clouds are moving further north and few cumuli exist over the southern Black Forest. At 1730 UTC the COPS area is free of clouds again.

As there is only minimal large-scale forcing and negligible buoyancy, at least in the flat Rhine valley, the line of convective clouds over the Black Forest must be triggered by local processes related to the orography. This is obvious from Fig. 9 showing the line of sight Doppler velocity measured by the DWD radar on top of the Feldberg in the southern Black Forest. The green line northeast of Freiburg indicates a component of the wind directed to the radar, while the red colour shows wind away from the radar. This means horizontal shear and convergence in this area. The convergence zone was firstly detected around 1100 UTC and propagated slowly towards the east. One hour later, this convergence leads to the development of the first convective clouds. At about 1600 UTC the convergent flow disappears in the radar image as do the cumulonimbus and smaller cumulus clouds.

Simultaneously, a north-south oriented convergence line also passes the mountain crests of the northern Black Forest from the west to the east. This convergence line forms in the transition zone between the surface low in the west and the surface high in the east. Additionally, thermally driven wind systems form a convergence zone along the mountain crests (Fig. 10), and up-valley winds develop, e.g. measured by sodar instruments in the Murg and Kinzig valleys (not shown). Upslope and up-valley winds transport relatively humid air up to the mountain range which then is forced to ascend over the mountain ridges by convergence. When the synoptically-induced convergence zone reaches the northern Black Forest, the different convergence zones superimpose optimally so that strong updraughts with subsequent cloud formation are observed. From the measurements it is not obvious, whether the northern and southern convergence lines are connected.

\subsection{Convection favoured by large-scale lifting (IOP 4b, June 20, 2007)}

The development of convection on this day was dominated by upper-tropospheric lifting, although there were several different forcing mechanisms. A ridge stretches from southern Scandinavia over the eastern Alps to the Adriatic Sea (Fig. 11) and moves slowly eastward, causing the prefrontal conditions described in the schematic diagram of Fig. 1. Between this ridge and a low over Ireland a strong south-westerly flow is present in the middle troposphere over the COPS domain. A jet streak stretches initially from Spain over western France to the south of the North Sea. Another one extends from the Spanish east coast to the Alps. At noon in the lower troposphere a frontal zone extends from southern Denmark over France towards central Spain. This frontal zone propagates slowly towards the east and affects the COPS area throughout the day. Ahead of the frontal zone, warm and moist air is transported in the lower troposphere from southwest towards northeast (Figs. 11 and 12), reflected by a tongue of high equivalent potential temperature of about $330 \mathrm{~K}$ that stretches from southeastern France to southwestern Germany. Figs. 12 and 13 indicate that the high moisture content is restricted to a layer below about $625 \mathrm{hPa}$ at $1400 \mathrm{UTC}$ and is higher in the southern (Burnhaupt) than in the northern (Achern and Karlsruhe) part of the COPS domain. For most of the investigation area a westerly wind 

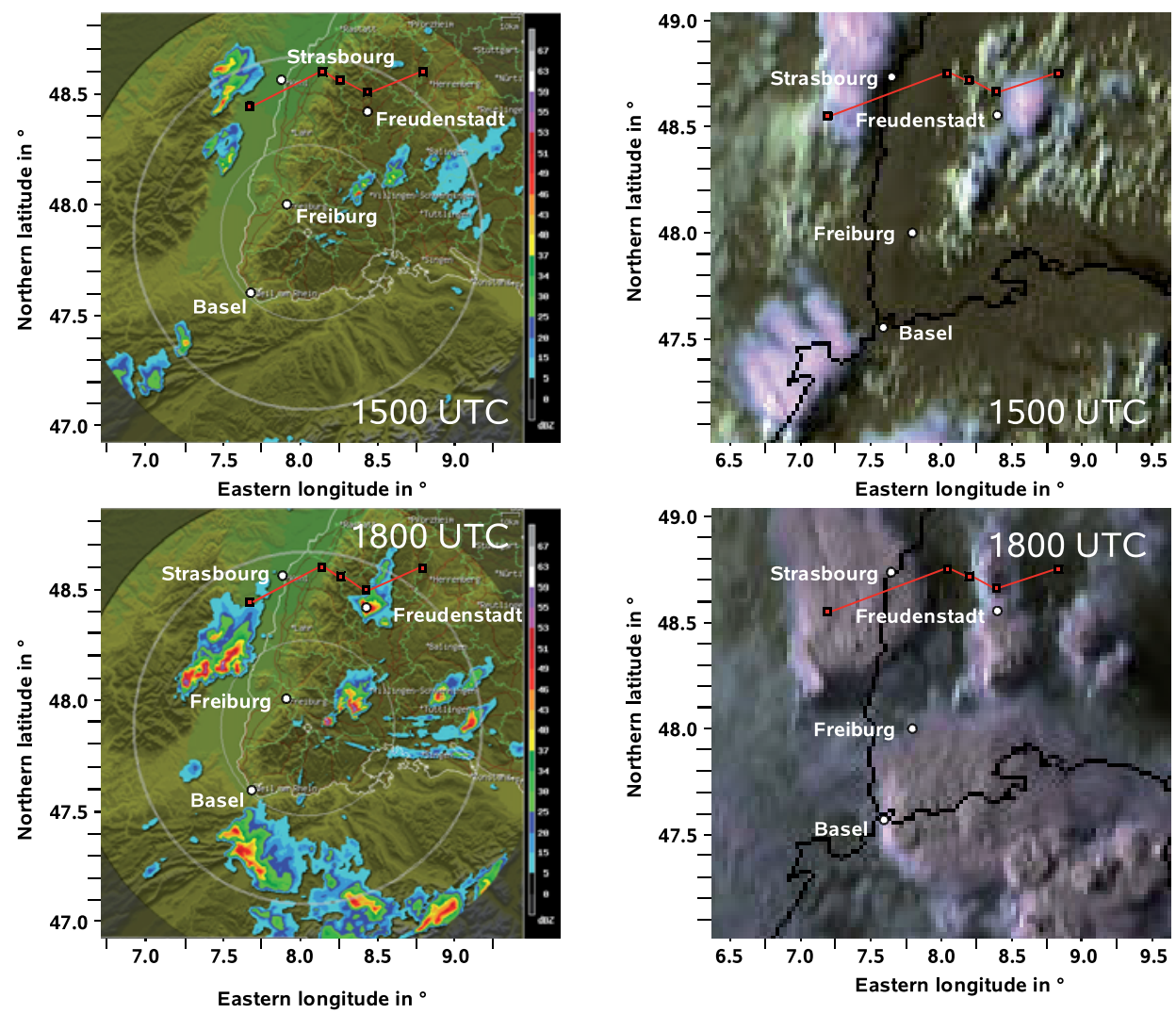

Figure 16: IOP 4b, June 20, 2007, 1500 UTC and 1800 UTC: Radar reflectivity indicating precipitation measured from DWD radar Feldberg (left) and MSG satellite images showing deep convection over the COPS area (right column). The red lines show the locations of the COPS supersites.

is found near the surface (Fig. 14). However, up-slope winds develop late in the morning on the Black Forest and Vosges slopes as well as up-valley winds in the valleys, as obvious at supersite $M$ in the Murg valley (Fig. 12). In the afternoon and early evening, moderate mid-tropospheric lifting of about $-8 \mathrm{hPa} \mathrm{h}^{-1}$ is analysed by the GFS in the southeastern part of the COPS domain, while in the northwestern part lifting is low (Fig. 15). This lifting is mainly caused by positive vorticity advection.

According to the synoptic conditions, the potential for convection exhibits a pronounced spatial distribution. In the southwestern part of the COPS area (Burnhaupt) the CAPE during the day increases from about $70 \mathrm{~J} \mathrm{~kg}^{-1}$ in the morning up to $1300 \mathrm{~J} \mathrm{~kg}^{-1}$ at $1400 \mathrm{UTC}$, but reaches only $450 \mathrm{~J} \mathrm{~kg}^{-1}$ in the north-western part (Karlsruhe) and is even less than $100 \mathrm{~J} \mathrm{~kg}^{-1}$ at Achern (Tab. 3). During this period CIN decreases to $42 \mathrm{~J} \mathrm{~kg}^{-1}$ at Karlsruhe and to $45 \mathrm{~J} \mathrm{~kg}^{-1}$ at Burnhaupt while it increases form about $85 \mathrm{~J} \mathrm{~kg}^{-1}$ to $136 \mathrm{~J} \mathrm{~kg}^{-1}$ at Achern. That means that CIN at Achern becomes even larger than the CAPE in the afternoon. This spatial distribution is also reflected by the KO index calculated from GFS data (Fig. 15). The KO index at $1800 \mathrm{UTC}$ is up to about $-18 \mathrm{~K}$ in the centre of the COPS area but much less in the northwestern part. The KO index, calculated from the indi- vidual radiosoundings, reveals the same spatial distribution although the absolute values are somewhat lower (KO $>-13 \mathrm{~K}$ at $1400 \mathrm{UTC}$ ). Similar findings concerning the spatial distribution are valid for the Lifted Index (Tab. 3). Thus, the convective indices describing the potential or latent instability of the atmosphere indicate that conditions for strong convection are higher in the southeastern than in the northwestern part of the COPS domain with a pronounced minimum in the Rhine valley at Achern. The convective temperature in the afternoon is about $28^{\circ} \mathrm{C}$ to $29^{\circ} \mathrm{C}$ at Burnhaupt and Karlsruhe and about $31^{\circ} \mathrm{C}$ at Achern. It is already attained by the nearsurface temperature at Burnhaupt in the morning and at Karlsruhe in the afternoon. However, it is not attained at Achern.

In summary, on this day widespread convection in different parts of the COPS area is obviously caused by different mechanisms, i.e. (i) initiation from the surface, because the near-surface temperature reaches the convective temperature in the southern and northern part of the COPS area in the afternoon, (ii) triggering by orographic effects, because the slope and valley winds favour air-mass convergence at the upper part of the valley and mountain crests, although both thermallydriven wind systems are weak on this day, and (iii) midtropospheric lifting, mainly in the south-western part of 


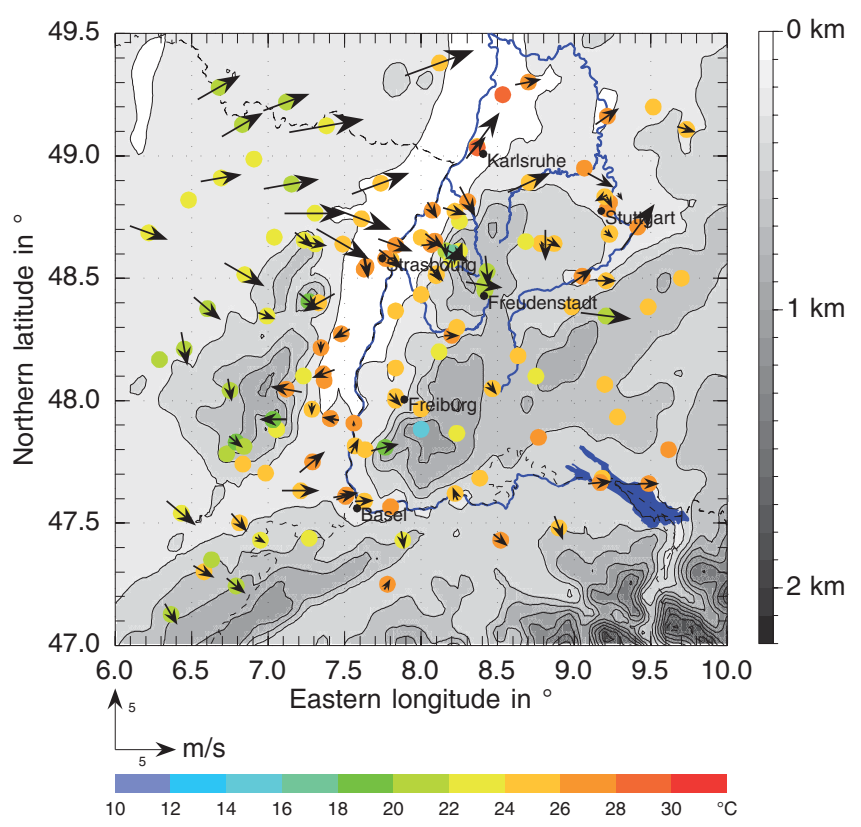

Figure 14: Near-surface wind (arrows) and temperature (colour code) on June 20, 2007, 1100 UTC.

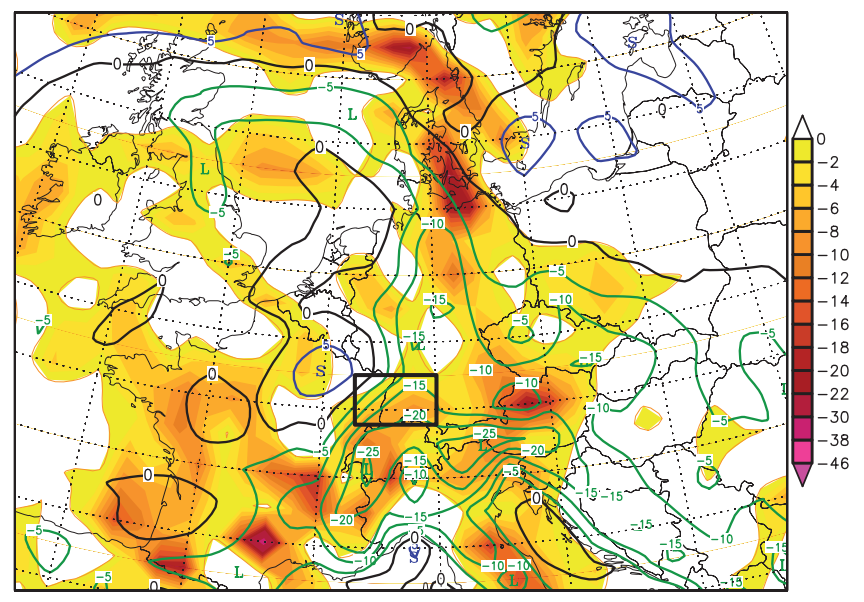

Figure 15: As Fig. 5 but GFS-analysis of IOP 4b, June 20, 2007, 1800 UTC.

the COPS domain. Finally, the convective indices like CAPE, LI and KO as well as the indices for convective inhibition show that convection is more likely in the southwest and less in the centre of the Rhine valley.

As is obvious from the satellite images and radar data, widespread shallow convective clouds already exist at 1030 UTC. However, only along and on the leeside of the mountain ranges of the Vosges and Black Forest mountains do they develop into deep precipitating convection in the afternoon, while the clouds disappear in the Rhine valley (Fig. 16), as expected from the above analysis. In the early afternoon, deep convection is mainly observed over the Vosges mountains and southern Black Forest, while in the late afternoon the convective activities also include the northern Black Forest (Fig. 16). The profiling systems even indicate that the convective system in the northern Black Forest at 1800 UTC (Fig. 13) causes a considerable inflow from the boundary layer into the convective system. That means, easterly wind is observed at supersite S, westerly wind at supersite $R$, and southerly wind at supersite $M$ (Fig. 12). The passage of the convective system at supersite $\mathrm{M}$ is accompanied by about $8 \mathrm{~mm}$ of precipitation.

\subsection{Convection near convergence lines or frontal zones (IOP 9c, July 20, 2007)}

The prototypic situation of convection initiation within a ridge - trough system (Fig. 1) is well represented by IOP $9 \mathrm{c}$, when convection is generated by a mid-tropospheric trough associated with a cold front and thermally driven mesoscale circulations along the front line which itself is enhanced by orographic effects and a gust front.

The synoptic situation at 1200 UTC is dominated by a quasi-stationary cut-off low at $500 \mathrm{hPa}$ over the British Isles and western France and a corresponding ridge extending from the Balkans to the North Sea (Fig. 17). There is a shallow trough embedded in the cut-off low, stretching from Normandy to northern Italy. Downstream of this trough a surface low developed over France in the preceding 30 hours and stretches from the English Channel to western Germany. In the lower troposphere the COPS area is affected slightly by warm air advection in the morning and more so by cold air advection in the afternoon. There is positive vorticity advection in the western part of the COPS area before noon. In the eastern part and in the afternoon the vorticity advection is negligible. On the synoptic scale this results in some forcing for lifting in the western COPS area $\left(-30 \mathrm{hPa} \mathrm{h}^{-1}\right)$ around noon. In the eastern COPS area, where the most severe convective development takes place, no large-scale forcing is analysed by the GFS model (Fig. 18). In this part, however, the potential instability, expressed by the KO index, is quite high (KO is up to $-15 \mathrm{~K}$ at $1200 \mathrm{UTC}$ between Black Forest and Swabian Jura). Over the Vosges, where higher lifting is expected, $\mathrm{KO}$ is slightly less than $-10 \mathrm{~K}$. As shown later, some sub-grid scale forcing processes (gust front and convergence line) initiate lifting just in the area of highest KO values and causes stronger convective development at the southern part of a cold front passing the COPS area (Fig. 17).

During the night of July 19 and morning of July 20 a mesoscale convective system (MCS) develops over eastern France, causing a surface pressure minimum at the western border of the COPS area (Fig. 17). There are showers in the MCS, while nighttime fog still exists in the Rhine valley and sky is clear over the Black Forest and east of it. Then convection develops quickly, associated with the formation and the north-easterly propagation of the cold front of the MSC. At 1200 UTC the centre of low pressure is located over western Germany with the cold front from north to south through the COPS area east of the Black Forest. Ahead of the front a thermally 


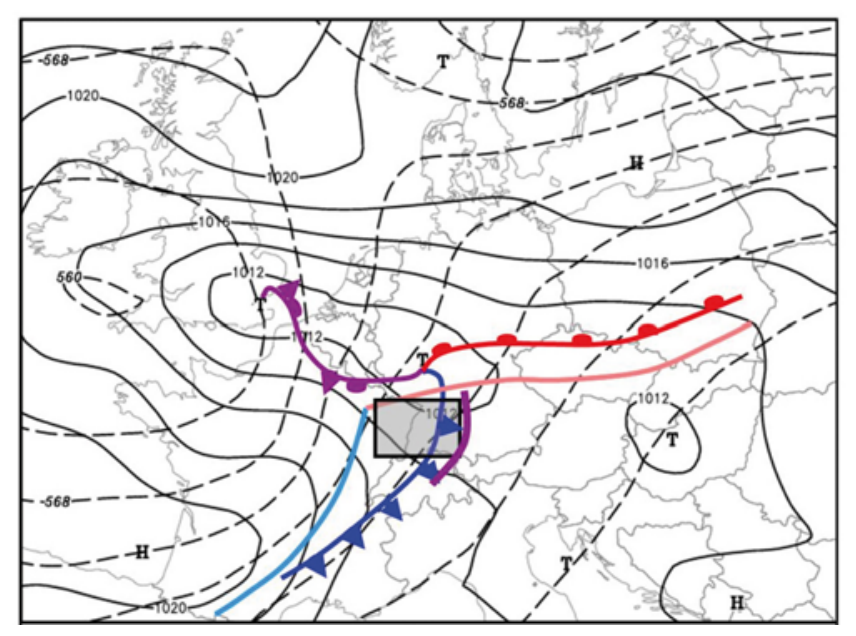

Figure 17: GFS-analysis of IOP 9c, July 20, 2007, 1200 UTC: surface pressure in $\mathrm{hPa}$ (solid lines), $500 \mathrm{hPa}$ in gpdm (dashed lines), and surface fronts (colour coded). The positions of the fronts at 0600 UTC are given in light red and blue. The COPS area is indicated by the shaded rectangle.

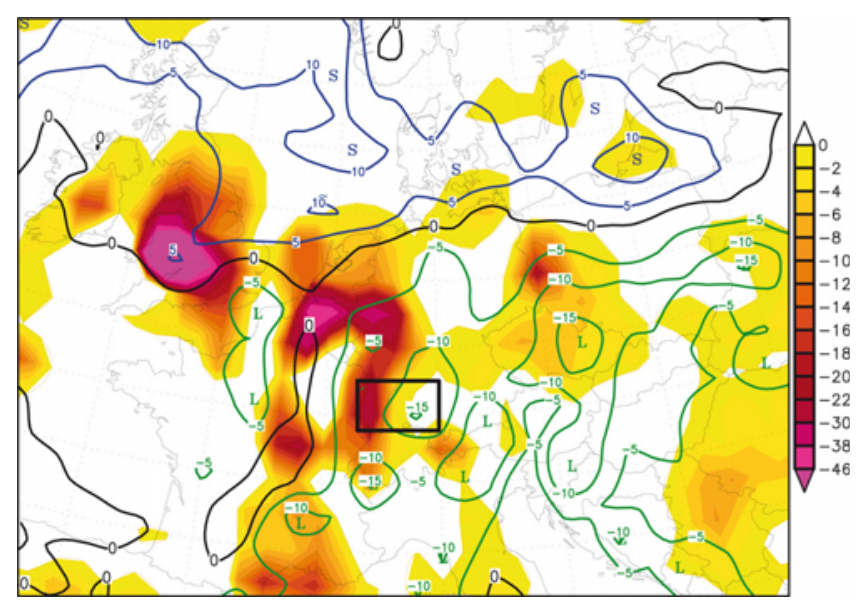

Figure 18: As Fig. 5 but GFS-analysis of IOP 9c, July 20, 2007, 1200 UTC.

driven circulation causes a convergence line (discussed below), initiating several new convective cells.

Fig. 19 shows details of the development between 0810 UTC and 1210 UTC with reflectivity data from the radar network of the DWD indicating precipitation and corresponding MSG satellite images (visible channel) provided by EUMETSAT. The satellite image from 0810 UTC shows the dissolving MCS over eastern France with an embedded line of showers at the edge of the cloud system over the Vosges. The Rhine valley between Karlsruhe and Strasbourg is covered by fog. During the next two hours the cloud system propagates to the northeast. When descending up to $800 \mathrm{~m}$ from the crest of the Vosges into the Rhine valley the convective clouds dissolve partly due to leeward subsidence and the showers are reduced significantly as indicated by the FZK precipitation radar (not shown). At
1010 UTC the first convective showers develop over the Black Forest north and south of Freudenstadt, triggered by orographic lifting and secondary circulations (Figs. 19 and 20). Subsequently, a second line of cumulonimbus clouds grows east of Freudenstadt at the leading edge of the cold front within the near surface convergence zone. At 1210 UTC 7 distinct convective cells are generated ranging from southwestern Germany to western Germany and the Netherlands in an arc-like structure (Fig. 19). Along the front widespread precipitation is detected with embedded severe showers. Behind the cold front over the Black Forest, the Rhine valley and the Vosges the surface pressure increases up to $3 \mathrm{hPa}$ within three hours and the development of organised secondary deep convection is reduced.

The reasons for the formation of the southern (and most severe) convective cells along the front are threefold: (i) a gust front with cold air originating from the nighttime MSC propagates eastward through the Rhine valley and initiates lifting, (ii) the orography of the Black Forest influences CI and (iii) the prefrontal heating by high insolation effects the formation of the prefrontal convergence.

A downdraught of cold $\left(18{ }^{\circ} \mathrm{C}\right)$ and moderately dry air (specific humidity $10 \mathrm{~g} \mathrm{~kg}^{-1}$ ) spreads out from the dissolving MCS in the morning over the Vosges. The gust front is recognisable by the arched cloud structure southwest of Strasbourg (Fig. 19, upper right). Passing the Rhine valley, the gust front reaches the western slope of the Black Forest at 0900 UTC between Karlsruhe and Strasbourg. The temperature at the foothills of the Black Forest is reduced by $6{ }^{\circ} \mathrm{C}$. Forming a cloud, the gust front ascends up to the plateau of the Black Forest (800 m MSL) and reaches the supersite Hornisgrinde at 0915 UTC. The wind increases from $2 \mathrm{~m} \mathrm{~s}^{-1}$ to $6.4 \mathrm{~m} \mathrm{~s}^{-1}$ (10 min mean) and the direction turns from ESE to W. Within 30 minutes the temperature decreases from $22.5{ }^{\circ} \mathrm{C}$ to $14.5^{\circ} \mathrm{C}$. At 0940 UTC the gust front reaches Igelsberg, $18 \mathrm{~km}$ east of supersite Hornisgrinde (Fig. 20). This results in a propagation speed of the front of $12 \mathrm{~m} \mathrm{~s}^{-1}$. At 1000 UTC the edge of the gust front has reached Freudenstadt $(22 \mathrm{~km}$ southeast of Hornisgrinde). The gust front forms an arch-like structure over the northern Black Forest. The mean wind speed behind the front is about $6 \mathrm{~m} \mathrm{~s}^{-1}$ coming from NW and the temperature is $20{ }^{\circ} \mathrm{C}$ or even less while ahead of the gust front the wind direction is $\mathrm{SE}$ and the air temperature lies between $24{ }^{\circ} \mathrm{C}$ and $28{ }^{\circ} \mathrm{C}$. The direction and speed of propagation is significantly modified by the main valleys of the rivers Murg, Enz, Rench and Kinzig (Fig. 20). There is some evidence that due to lifting by the gust front and orographic effects the initiation of convection in the Freudenstadt area (Fig. 19) is now enhanced. 

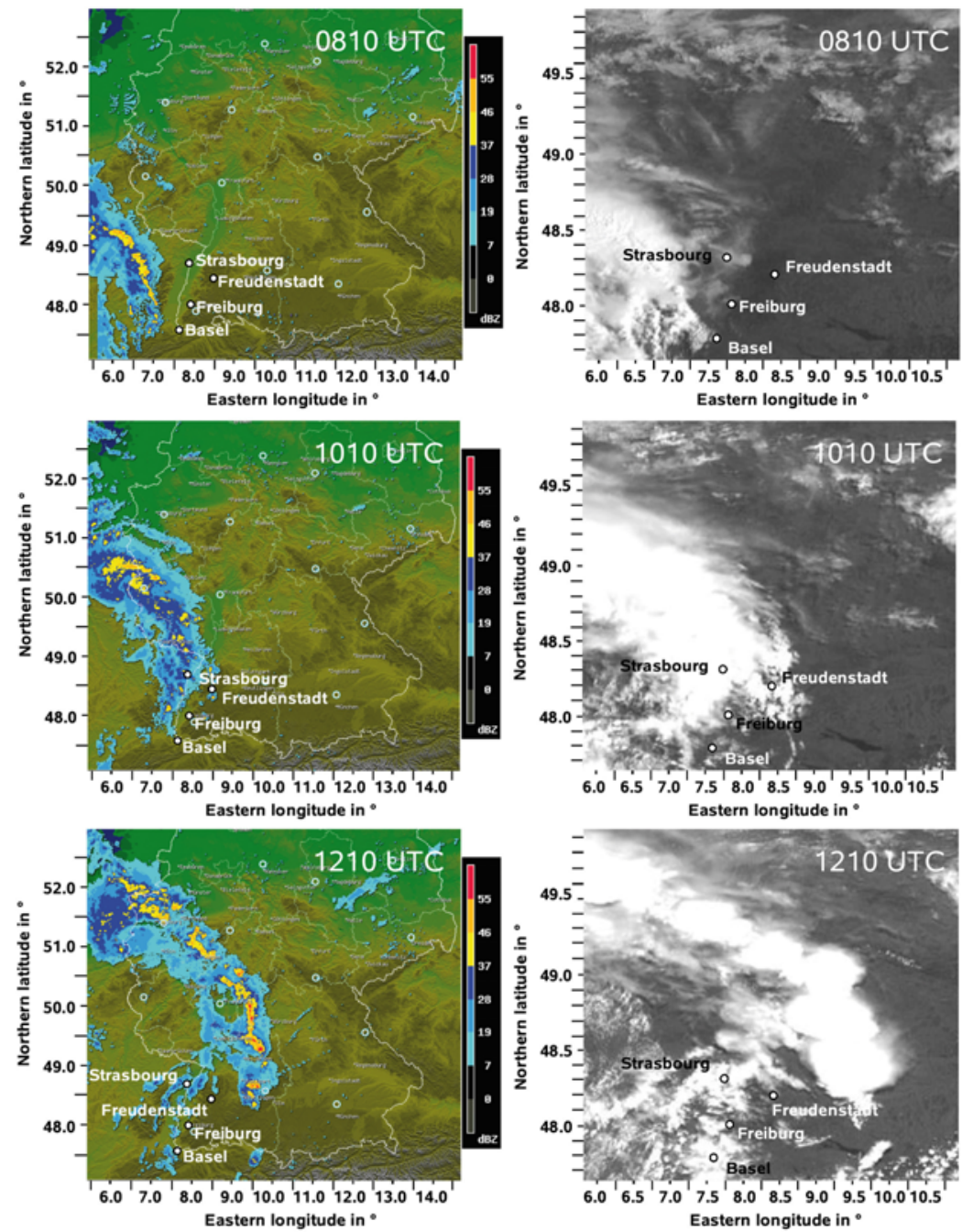

Figure 19: IOP 9c, July 20, 2007, 08101010 and 1210 UTC: Radar reflectivity indicating precipitation measured by the DWD radar network and corresponding MSG satellite images showing deep convection development over the COPS area.

Two hours later, at 1200 UTC, the near surface temperature in the Stuttgart area and south of it over the Swabian Jura reaches $28{ }^{\circ} \mathrm{C}$ to $30^{\circ} \mathrm{C}$ due to high insolation. Over the Black Forest the air temperature is $8{ }^{\circ} \mathrm{C}$ to $12{ }^{\circ} \mathrm{C}$ lower, caused by cloud shading, showers and the cold air originating from the gust front. This leads to an enhanced horizontal temperature gradient initiating a thermally driven circulation with the development of a convergence line, located over Stuttgart, the Swabian Jura, and ending east of Basel (Fig. 20). The three most southern cumulonimbus clouds in Fig. 19 roughly indicate the position of the convergence zone.

The stratification is shown in Fig. 21 and the respective convective indices are given in Tab. 4. Vertical soundings made north of Karlsruhe (FZK, Fig. 3) at 0800,1100 and 1400 UTC indicate the passage of the gust front before 1100 UTC. Between 0800 UTC and 1100 UTC the wind turns from E, SE and S to WSW between the surface and $850 \mathrm{hPa}$ and the wind speed increases from $2 \mathrm{~m} \mathrm{~s}^{-1}$ to $18 \mathrm{~m} \mathrm{~s}^{-1}$. The profiles of potential temperature show stable stratification above $940 \mathrm{hPa}$. The potential instability, expressed by $\Theta_{e}$, shows significant differences. Above $950 \mathrm{hPa}$ up to $600 \mathrm{hPa}$ and $520 \mathrm{hPa}$, respectively, all profiles indicate potential instability by decreasing values of $\Theta_{e}$ with height. All profiles are characterised by thick unstable layers alternating with few thin stable layers in varying heights between 0800 UTC and 1400 UTC. The reason may be differential advection and/or vertical motion. At 0800 UTC the $\Theta_{e}$ gradient is approximately $2 \mathrm{~K}$ per $100 \mathrm{hPa}$. After the passage of the gust front at $1100 \mathrm{UTC}$ it exceeds up to $4.5 \mathrm{~K}$ per $100 \mathrm{hPa}$ but decreases again down to $1.3 \mathrm{~K}$ per $100 \mathrm{hPa}$ at $1400 \mathrm{UTC}$ when the cold air after the gust front has passed the site. The highest variability in the $\Theta_{e}$ profile is around 1100 UTC when the convective development is at its maximum. The $\mathrm{KO}$ index in the Rhine valley between Karlsruhe and Burnhaupt is between $-2 \mathrm{~K}$ and $-9 \mathrm{~K}$. This is clearly west of the maximum of potential instability (Fig. 18) and consequently no severe convection is found in the Rhine valley. 

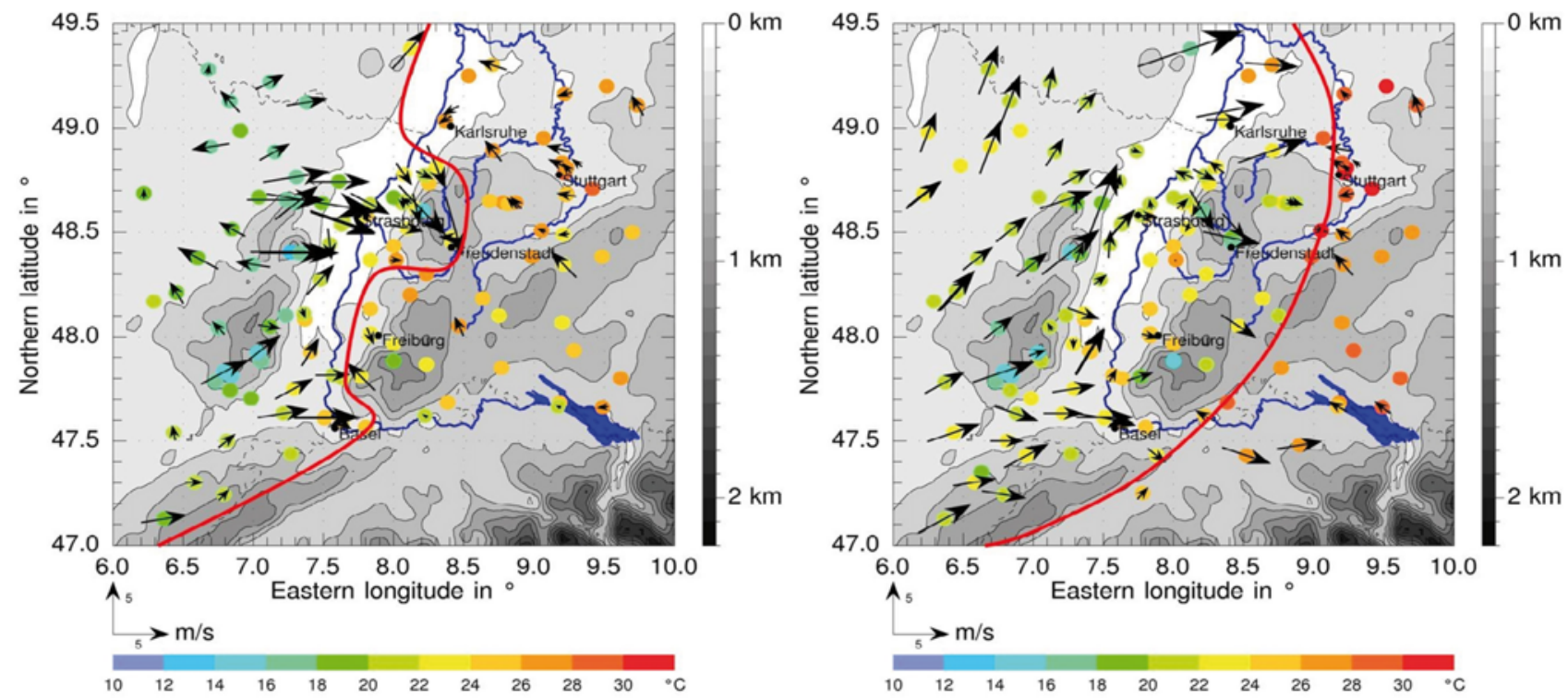

Figure 20: Near-surface wind (arrows) and temperature (colour code) on July 20, 2007, at 1000 UTC (left) and 1200 UTC (right). The gust front (left) and cold front positions (right) are given by the red line.

Table 4: Convective indices during IOP 9c (July 20, 2007) at COPS sites Burnhaupt, Karlsruhe and supersite V (Meistratzheim, Fig. 3): Explanation of abbreviations: see Tab. 2.

\begin{tabular}{|l|c|c|c|c|c|c|}
\hline Burnhaupt \\
\hline UTC & CAPE $\left(\mathrm{J} \mathrm{kg}^{-1}\right)$ & $\mathrm{CIN}\left(\mathrm{J} \mathrm{kg}^{-1}\right)$ & $\mathrm{T}_{\text {t trig }\left({ }^{\circ} \mathrm{C}\right)}$ & $\mathrm{T} \_2 \mathrm{~m}\left({ }^{\circ} \mathrm{C}\right)$ & $\mathrm{KO}(\mathrm{K})$ & $\mathrm{LI}(\mathrm{K})$ \\
\hline 0500 & 68 & 427 & 32.5 & 16.6 & -8.9 & 2.5 \\
\hline 0800 & 0 & 162 & 27.7 & 22.8 & -2.0 & -3.3 \\
\hline 1100 & 39 & not def. & 28.9 & 22.3 & -1.8 & -1.8 \\
\hline 1400 & 220 & 110 & 23.5 & 22.6 & -7.8 & -5.3 \\
\hline 1700 & 2 & 11 & 22.7 & 22.3 & -5.4 & -1.6 \\
\hline Karlsruhe & \multicolumn{7}{|l}{} \\
\hline 0500 & 6 & not def. & 32.5 & 17.1 & -3.6 & 3.3 \\
\hline 0800 & 122 & 363 & 31.3 & 25.0 & -8.0 & -3.6 \\
\hline 1100 & 37 & 120 & 25.0 & 25.1 & -2.1 & -3.1 \\
\hline 1400 & 68 & 281 & 31.8 & 21.8 & -4.9 & -1.6 \\
\hline 1700 & 144 & 114 & 25.3 & 25.2 & -4.2 & -3.9 \\
\hline 2000 & not def. & not def. & 24.9 & 22.6 & -4.4 & 1.4 \\
\hline Meistratzheim & \multicolumn{7}{|l|}{} \\
\hline 0515 & 139 & 413 & 33.3 & 17.9 & -5.9 & 0.1 \\
\hline 0815 & 270 & 406 & 34.0 & 21.2 & -8.7 & -2.7 \\
\hline 1115 & 107 & not def. & 31.6 & 19.5 & -3.2 & 0.4 \\
\hline 1415 & 269 & 93 & 25.6 & 24.9 & -4.5 & -1.5 \\
\hline 1715 & 33 & not def. & 25.9 & 24.0 & -7.5 & -0.8 \\
\hline
\end{tabular}

Summarising, the initiation of convection is triggered by the interaction of convection-driving forces on different scales. These processes are: (i) Large-scale lifting which causes the surface low with the development of the cold front. (ii) Prefrontal convergence generated by adjacent areas with insolation and cloud shading (see
Fig. 2). (iii) A gust front with cool and dry air moving eastward over the central part of the northern Black Forest, regionally enhancing the horizontal temperature gradient over the mountains, while the large scale easterly flow of warm and humid air is still present. (iv) Locally, caused by the orography, the horizontal temper- 

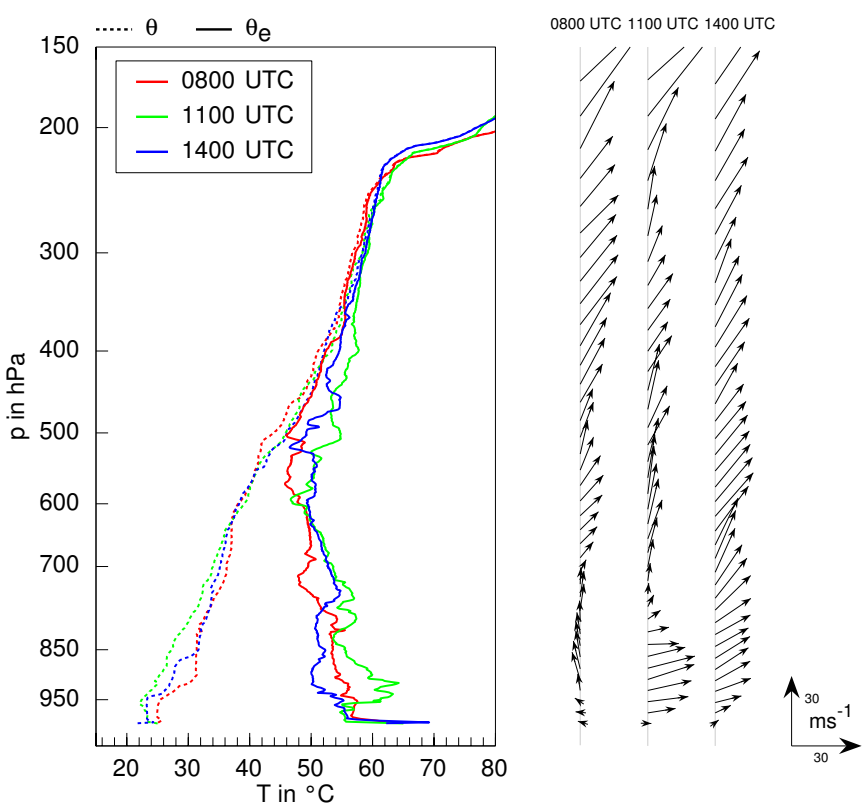

Figure 21: IOP 9c, July 20, 2007: Vertical profiles of potential temperature, equivalent potential temperature and horizontal wind from 0800, 1100 and 1400 UTC at the northern COPS site Karlsruhe (FZK).

ature gradient is additionally enhanced at the head of the gust front, which causes cumulus congestus clouds to develop. Finally, the source of the gust front, the low pressure system generated by the MCS over eastern France, moves to the northeast. Ahead of the southern part of its cold front, severe convective cells develop along the convergence line mentioned above. The widespread lower tropospheric cold and dry air behind the cold front reaches the Black Forest much later in the day.

On the one hand the large-scale feature of this development, the formation of the secondary low originating from the MSC, its propagation to the northeast and the generation of the cold front with convective precipitation was reasonably well predicted by the COSMO model of the DWD. On the other hand, the gust front, the convergence line, their interaction and the influence of orography and subsequently convection and convective precipitation were very poorly simulated.

\section{Conclusions}

There was a total of 18 IOPs during COPS. The whole set-up of instrumentation was well coordinated so that the complete life cycle of convective systems was captured. The long observation period of three months allowed for the investigation of a wide range of convective situations with different initiation mechanisms over complex terrain. The lower boundary condition led to the evolution of different mesoscale processes so that even under all these different large-scale conditions boundary-layer processes significantly triggered and/or modified deep convection.
Three days were presented on which most of the typical initiation mechanisms were present. It is shown for IOP $8 \mathrm{~b}$ (type I, Tab. 1) that several hours before deep convection is initiated, convergence lines were observed in that area by radar, sodar, and lidar. This is much earlier than reported in other investigations (e.g. WILSON et al., 1998). The detection and propagation of mesoscale convergence lines was only feasible due to the high temporal and spatial distribution of remote sensing systems. That means the detection of those convergence lines facilitates nowcasting to a certain extent when adequate observations are available. If in general the conditions for $\mathrm{CI}$ are favourable, due to advection of warm and moist air and mid-tropospheric lifting such as during IOP $4 \mathrm{~b}$ (typ II, Tab. 1), the spatial distribution of these variables turns out to be indicative for the region of preferred CI even when obtained from a coarser-resolution global model (GFS). These predictors have to be properly weighted compared to boundarylayer and orographic influences, which on the one hand tend to suppress convection in extended lower regions upstream of mountains such as the Rhine valley while on the other hand orographically-induced convergence triggered convection over the mountain crests on IOP $4 \mathrm{~b}$. Nowcasting of convection for IOP 9c (type III, Tab. 1) may be degraded by intermediate suppression of frontal convection-related phenomena such as clouds and precipitation, when the mesoscale front passes over a wide valley such as the Rhine valley. Secondary downstream CI may then occur due to differential surface heating near the margin of the overcast region and/or by gust fronts.

All three IOPs prove to be appropriate prototypes representing the main trigger mechanisms of deep convection over complex terrain. It can be expected that by exploitation of the full data set of each IOP even a more detailed understanding of the contributing processes for CI can be achieved. Especially, use of aircraft, GPS, and high resolution lidar data will give additional information concerning CI-related processes. Additionally, these IOPs are excellent cases for studying the performance of mesoscale models concerning convective precipitation. In general we recommend that a model validation strategy specific for the type of convection is necessary to analyse the model deficiencies and to improve the overall forecast skills.

\section{Acknowledgments}

The authors wish to thank the Deutsche Forschungsgemeinschaft (DFG) for funding the Priority Program SPP 1167 in which COPS was embedded. We also thank the Deutscher Wetterdienst (DWD) for providing surface station and radar data as well as the European Organisation for the Exploitation of Meteorological Satellites (EUMETSAT) for Meteosat-8 Rapid Scans. Additional surface station data was kindly provided by the 
Landesanstalt für Umwelt, Messungen und Naturschutz Baden-Württemberg (LUBW). The Austrian contribution was funded by the Project CONSTANCE P-19658 of the Austrian Science Fund (FWF). We are also grateful to the Atmospheric Radiation Measurement (ARM) Program for operating the ARM Mobile Facility. The French contribution was supported by Centre National d'Etudes Spatiales (CNES), Agence Nationale de la Recherche (ANR, project COPS-France), Institut Nationale des Sciences de l'Univers (INSU, programme LEFE) and Météo-France. The UK contribution was supported by the Natural Environment Research Council.

\section{References}

Aoshima, F., A. Behrendt, H.-S. BAuer, V. WULFMEYER, 2008: Statistics of convection initiation by use of Meteosat Rapid Scanning data during the Convective and Orographically-Induced Precipitation Study (COPS). - Meteorol. Z. 17, 921-930.

Barthlott, Ch., U. Corsmeier, C. Meissner, F. Braun, CH. KotTMEIER, 2006: The influence of mesoscale circulation systems on triggering convective cells over complex terrain. - Atmos. Res. 81, 150-175.

Browning, K., A. Blyth, P. Clark, U. Corsmeier, C. Morcrette, J. Agnew, D. Bamber, Ch. Barthlott, L. BennetT, K. Beswick, M. Bitter, K. Bozier, B. Brooks, C. Collier, C. CoOK, F. Davies, B. Deny, T. Feuerle, R. Forbes, C. GAFFArd, M. Gray, R. HANKERS, T. HEWISON, N. KALTHOFF, S. KHODAYAR, M. Kohler, Ch. Kottmeier, St. Kraut, M. KunZ, D. LAdD, J. Lenfant, J. MARSham, J. McGregor, J. Nicol, E. Norton, D. PARKer, F. PERry, M. RAMATSChi, H. Ricketts, N. Roberts, A. Russell, H. Schulz, E. Slack, G. VAughan, J. WAight, R. WatSON, A. WEBB, A. WIESER, 2007: The convective storm initiation project. - Bull. Amer. Meteor. Soc. 88, 19391955.

Chaboureau, J.-P., F. Guichard, J.-L. ReDELSPERGER, J.-L. LAFORE, 2004: The role of stability and moisture in the diurnal cycle of convection over land. - Quart. J. Roy. Meteor. Soc. 130, 3105-3117.

Crewell, S., M. Mech, T. Reinhardt, C. Selbach, H.-D. Betz, E. BROCARD, G. Dick, E. O'CONNOR, J. Fischer, T. Hanisch, T. Hauf, A. Hünerbein, L. Delobbe, A. Mathes, G. Peters, H. Wernli, V. WULFMEYER, 2008: The general observation period 2007 within the priority program on quantitative precipitation forecasting: Concept and first results - Meteorol. Z. 17, 849-866.

Eigenmann, R., S. Metzger, L. Siebicke, K. StaudT, A. SERAFIMOVICH, T. FOKEN, 2008: Generation of free convection in a valley due to changes of the local circulation system. - Extended abstract $18^{\text {th }}$ Symposium on Boundary Layers and Turbulence, AMS, Stockholm 2008, Poster P5.1, http://ams.confex.com/ams/pdfpapers/139528.pdf

FiEdLER, F., I. BischofF-Gauss, N. KALTHOFF, G. ADRIAN, 2000: Modeling of transport and dispersion of SF6 in the Freiburg-Schauinsland area. - J. Geophys. Res. 105, 1599-1610.
Groenemeijer, P., CH. BARThlott, A. Behrendt, U. Corsmeier, J. Handwerker, M. Kohler, CH. Kottmeier, H. Mahlke, S. Pal, M. Radlach, J. TrEnTMANN, A. WIESER, V. WULFMEYER, accepted: Multi-sensor measurements of a convective storm cluster over a low mountain range: adaptive observations during PRINCE. - Mon. Wea. Rev.

Kalthoff, N., H.-J. Binder, M. Kossmann, R. VöGTLIN, U. CORSMEIER, F. Fiedler, H. SCHLAGER, 1998: Temporal evolution and spatial variation of the boundary layer over complex terrain. - Atmos. Environ. 32, 1179-1194.

KalthofF, N., V. Horlacher, U. CORSMEIER, A. Volz-Thomas, B. Kolahgar, H. GeISS, M. MÖllmann-COERS, A. KNAPS, 2000: The influence of valley winds on transport and dispersion of airborne pollutants in the Freiburg-Schauinsland area. - J. Geophys. Res. 105, 1585-1597.

Kossmann, M., F. Fiedler, 2000: Diurnal momentum budget analysis of thermally induced slope winds. - Meteor. Atmos. Phys. 75, 195-215.

Kossmann, M., R. VÖGtlin, U. Corsmeier, B. Vogel, F. FIEDLER, H.-J. BINDER, N. KALTHOFF, F. BEYRICH, 1998: Aspects of the convective boundary layer structure over complex terrain. - Atmos. Environ. 32, 1323-1348.

Kossmann, M., U. Corsmeier, S.F.J. DeWeKker, F. Fiedler, R. Vögtlin, N. Kalthoff, H. GÜsten, B. NEININGER, 1999: Observations of hand over processes between the atmospheric boundary layer and the free troposphere over mountainous terrain. - Contr. Atmos. Phys. 72, 329-350.

Krauss, L., CH. Barthlott, Ch. Hauck, G. SCHÄDleR, N. KalthofF, CH. KotTMEIER, submitted: Soil moisture monitoring network in Southwest Germany: regional analysis and comparison to GME/COSMO-DE model values. - Meteorol. Z.

KURZ, M., 1984: Leitfäden für die Ausbildung im Deutschen Wetterdienst, Nr. 8: Synoptische Meteorologie. - Selbstverlag des Deutschen Wetterdienstes, Offenbach am Main.

Lascaux, F., E. Richard, C. Keil, O. Bock, 2004: Impact of the MAP reanalyis on the numerical simulation of the MAP-IOP2a convective system. - Meteorol. Z. 13, 49-54.

Meissner, C., N. Kalthoff, M. Kunz, G. Adrian, 2007: Initiation of shallow convection in the Black Forest mountains. - Atmos. Res. 86, 42-60.

Rotach, M.W., M. Arpagaus, M. Dorninger, C. Hegg, J. Frick, A. Montani, R. Ranzi, F. BoutTIER, A. Buzzi, G. Frustaci, K. Mylne, E. Richard, A. Rossa, C. Schär, M. Staudinger, H. VOlKert, V. WulfMEYER, H.-S. BAUER, F. AMENT, M. DEnhard, F. Fundel, U. GERMANN, AND M. STOLL, submitted: MAP D-PHASE: Real-time Demonstration of Weather Forecast Quality in the Alpine Region. - Bull. Amer. Meteor. Soc.

SChëtTler, U., G. Doms, C. SCHRAFF, 2008: A description of the nonhydrostatic regional COSMO-Model, Part VII: User's Guide. - available at www.cosmo-model.org

SChWitAlla, T., G. ZäNGL, H.-S. BAUER, V. WULFMEYER, 2008: Systematic errors of QPF in low-mountain regions. - Meteorol. 17, 903-919.

WECKWERTH, T.M., 2000: The effect of small-scale moisture variability on thunderstorm initiation. - Mon. Wea. Rev. 128, 4017-4030. 
WECKWERTh, T.M., D.B. PARSONS, 2006: A review of convection initiation and motivation for IHOP_2002. Mon. Wea. Rev. 134, 5-22.

Weckwerth, T.M., D.B. Parsons, S.E. Koch, J.A. Moore, M.A. LeMone, B. Demoz, C. Flamant, B. GEERTS, J. WANG, W.F. FELTZ, 2004: An overview of the international $\mathrm{H} 2 \mathrm{O}$ project (IHOP-2002) and some preliminary highlights. - Bull. Amer. Meteor. Soc. 85, 253-277.

Wilson, J.W., R.D. RobERTS, 2006: Summary of convective storm initiation and evolution during IHOP: Observational and modeling perspective. - Mon. Wea. Rev. 134, 23-47.

Wilson, J.W., W.E. Schreiber, 1986: Initiation of convective storms at radar-observed boundary-layer convergence lines. - Mon. Wea. Rev. 114, 2516-2536.

Wilson, J.W., N.A. Crook, C.K. Mueller, J. Sun, M. DIXON, 1998: Nowcasting thunderstorms: A status report. - Bull. Amer. Meteor. Soc. 79, 2079-2099.

Wulfmeyer, V., A. Behrendt, Ch. Kottmeier, U. Corsmeier, G. Adrian, H.-S. Bauer, A. Blyth, E. Browell G. Craig, S. Crewell, K.J. DAVIS, R. DiRKS, H. GRASSL, M. HAGEN, R.M. HARDESTY, J. HeintzenberG, L. Kornblueh, J. Lelieveld,
E. Richard, M. ROTACH, H. RUSSCHEnberG, U. SCHUMANN, R. STEINACKER, H. VOLKERT, T.M. WECKWERTH, H. WERNLI, J.W. WILSON, 2006: COPS science overview document. - available at www.unihohenheim.de/cops/further_reading/further_reading.htm

Wulfmeyer, V., A. Behrendt, H.-S. BAuer, C. Kottmeier, U. Corsmeier, A. Blyth, G. Craig, U. Schumann, M. Hagen, S. Crewell, P. Di Girolamo, C. Flamant, M. Miller, A. Montani, S. Mobbs, E. Richard, M.W. Rotach, M. Arpagaus, H. RusschenberG, P. SChlüSSEl, M. KÖNIG,, V. GÄrtner, R. SteinaCKer, M. DORninger, D.D. Turner, T. Weckwerth, A. Hense, C. Simmer, 2008: The Convective and Orographically-induced Precipitation Study: A research and development project of the world weather research program for improving quantitative precipitation forecasting in low-mountain regions. - Bull. Amer. Meteor. Soc. 89, 1477-1486, DOI 10.1175/2008BAMS2367.1.

Zus, F., M. GrZeschiK, H.-S. BAUER, V. WulfMeyer, 2008: Design and optimization of the IPM GPS slant path 4DVAR system. - Meteorol. Z. 17, 867-885. 